DIW BERLIN

Discussion

Papers
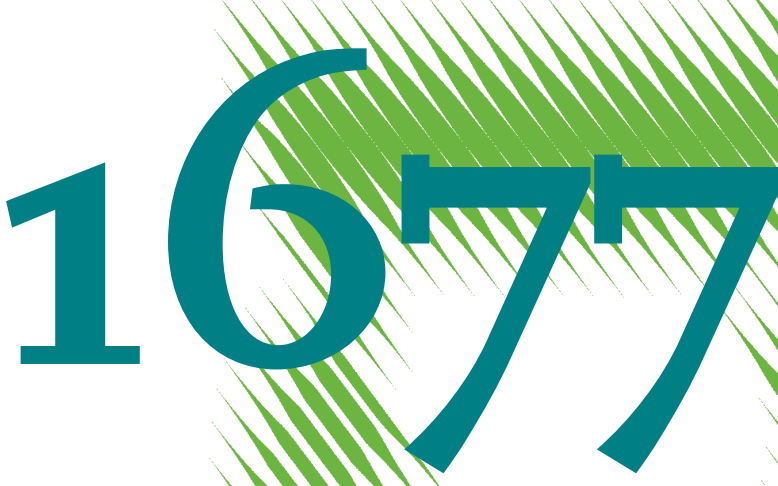

(a)
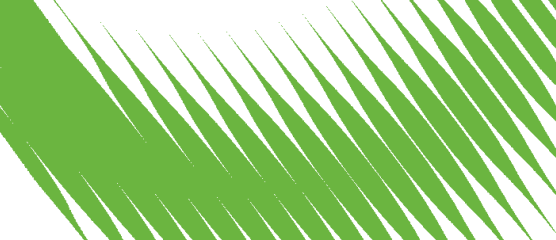

1111111

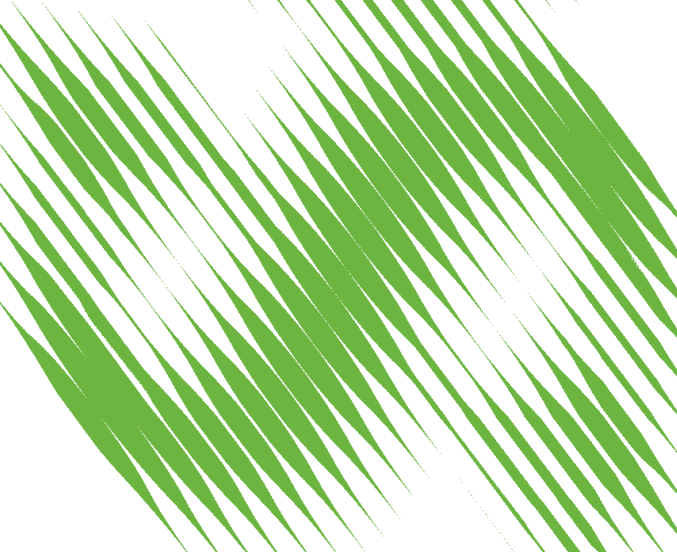

MMI

MIMIMIMIM

Power-to-Heat for Renewable Energy Integration: Technologies, Modeling Approaches, and Flexibility Potentials 
Opinions expressed in this paper are those of the author(s) and do not necessarily reflect views of the institute.

IMPRESSUM

(C) DIW Berlin, 2017

DIW Berlin

German Institute for Economic Research

Mohrenstr. 58

10117 Berlin

Tel. +49 (30) $89789-0$

Fax +49 (30) $89789-200$

http://www.diw.de

ISSN electronic edition 1619-4535

Papers can be downloaded free of charge from the DIW Berlin website:

http://www.diw.de/discussionpapers

Discussion Papers of DIW Berlin are indexed in RePEc and SSRN:

http://ideas.repec.org/s/diw/diwwpp.html

http://www.ssrn.com/link/DIW-Berlin-German-Inst-Econ-Res.html 


\title{
Power-to-heat for renewable energy integration: Technologies, modeling approaches, and flexibility potentials
}

\author{
Andreas Bloess $^{\mathrm{a}, \mathrm{b}}$, Wolf-Peter Schill ${ }^{\mathrm{b}}$, Alexander Zerrahn ${ }^{\mathrm{b}}$ \\ ${ }^{a}$ Workgroup for Infrastructure Policy (WIP) at Berlin Institute of Technology (TU \\ Berlin), Straße des 17. Juni 135, D-10623 Berlin, Germany, agb@wip.tu-berlin.de. \\ ${ }^{b}$ German Institute for Economic Research (DIW Berlin), Mohrenstr. 58, D-10117 \\ Berlin, Germany
}

\begin{abstract}
Flexibly coupling power and heat sectors may contribute to both renewable energy integration and decarbonization. We present a literature review of model-based analyses in this field, focusing on residential heating. We compare geographical and temporal research scopes and identify state-ofthe-art analytical model formulations, particularly concerning heat pumps and thermal storage. While numerical findings are idiosyncratic to specific assumptions, a synthesis of results generally indicates that power-to-heat technologies can cost-effectively contribute to fossil fuel substitution, renewable integration, and decarbonization. Heat pumps and passive thermal storage emerge as particularly favorable options.
\end{abstract}

Keywords: power-to-heat, renewable energy, decarbonization, heat pump, thermal energy storage

JEL codes: C61, D62, Q42 


\section{Introduction}

Not only since the 2015 Paris Agreement[1], there is widespread consensus that the use of renewable energy sources will play a major role in the global response to the threat of climate change. In particular, increasing shares of variable renewable energy sources such as wind and solar power must be integrated in different end-use sectors. In this context, the coupling of power and heat sectors receives increasing attention of researchers and policymakers alike. Compared to other flexibility options and sector coupling strategies, linking the power and heat sectors is often considered to be particularly promising because both the costs of generating heat from electricity and the costs of heat storage are relatively low [2]. Flexibly using renewable electricity for heating purposes may (i) help to decarbonize the heat sector, and (ii) contribute to the power system integration of variable renewables by providing additional flexibility.

In many industrialized countries, decarbonizing the heating sector is a precondition for achieving ambitious climate policy targets; in particular, space heating accounts for substantial fractions of final energy demand and greenhouse gas emissions [3]. Compared to the electricity sector, the utilization of renewable energy sources lags behind in the heat sectors in many countries. For example, Germany is often considered as an international front-runner with respect to the utilization of wind and solar energy [4]. By the end of 2016, the share of renewables in gross power consumption was nearly $32 \%$ in Germany, up from around 3\% in the early 1990s. In contrast, the renewable share in final energy demand for heating and cooling was only around $13 \%$ in 2016, up from 2\% in 1990 [cf. 5]. Similar pictures prevail in other industrialized countries.

The integration of variable renewable energy sources requires additional flexibility in the power system as the feed-in patterns of wind and solar power are only partly correlated with electricity demand [cf. 6, 7, 8]. There are many ways of providing such flexibility, for example, flexible thermal genera- 
tors, various forms of energy storag $\biguplus^{1}$, demand-side measures, grid-connected electric vehicles, geographical balancing facilitated by transmission, as well as changes in design, siting, and dispatch of variable renewables [10]. While, traditionally, generating heat from electricity was not a preferred option, the flexible use of electricity for heating purposes, often combined with heat storage, has recently received increasing attention as another potential source of additional power system flexibility [11].

While the benefits and challenges of power-to-heat options in power systems with high shares of variable renewable energy sources are beginning to be understood, the literature is still heterogeneous: existing power system models have been extended and new models have been developed; with applications focusing on various geographical contexts, analysis horizons, and technologies. To consolidate the evidence at hand and lay out avenues for future research, we devise a structured account of model-based analyses of different power-to-heat options in the international peer-reviewed literature. In particular, we compare scopes, methodologies, and research questions and aim to synthesize some common findings.

In doing so, we focus on power system effects of power-to-heat technologies in the residential heating sector and largely exclude industrial heat applications. We further focus on power-to-heat options, that is, turning electric into thermal energy, and not on the combined generation of heat and power (CHP). We do not consider other sector coupling strategies, for example, interactions between electric vehicle batteries and the power system [for an overview, see 12], or conversion paths like power-to-gas or power-to-liquids [see, for instance, 13, 14, 15].

The remainder of this article is structured as follows. In Section 2, we categorize different power-to-heat options, that is, different approaches of using electricity in the residential heating sector. Section 3 introduces the methodology of our literature review. In Section 4, we discuss the research scope of model-based power-to-heat analyses in the international literature. Sec-

\footnotetext{
${ }^{1} \mathrm{~A}$ review of electricity storage requirements for renewable energy integration is pro-
} vided by 9 . 
tion 5 compares methodological approaches and introduces analytical model formulations of heat pumps and heat storage. In Section 6, we synthesize research questions and findings with respect to, among others, cost effectiveness, integration of variable renewables, and decarbonization.

\section{Residential power-to-heat options}

There are different means to convert electricity into heat. Figure 1 categorizes the most important options for the residential heating sector.

Figure 1: Categorization of residential power-to-heat options

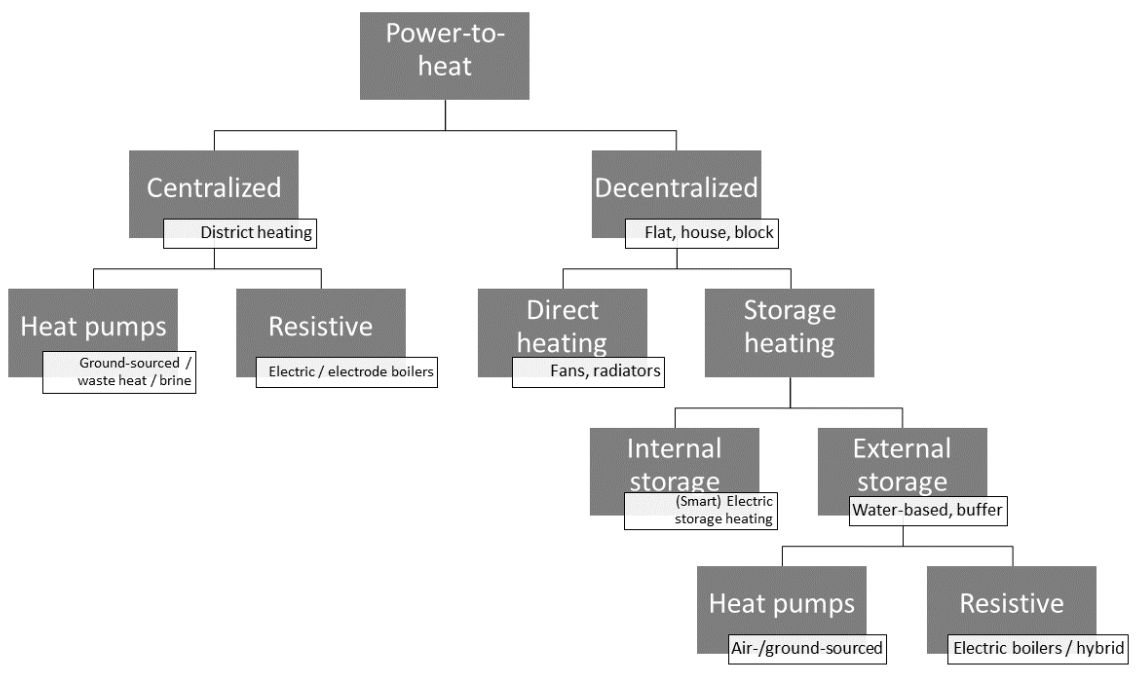

Source: Own illustration.

First, we distinguish between centralized and decentralized power-to-heat options. Under the centralized approach, electricity is converted into heat at a location that may be distant to the point of actual heat demand, and (district) heating networks are used to distribute the heat to where it is needed [16]. In contrast, decentralized power-to-heat options make use of electricity right at, or very close to, the location of heat demand. In reality, the line between centralized and decentralized options is blurred as, for ex- 
ample, heat may be jointly provided for only a few flats or houses in local or neighborhood heating networks [17].

Second, some power-to-heat options involve thermal energy storage, while others do not. Centralized options always come with some extent of storage because district heating networks have a certain thermal storage capacity [18. A heating network's storage capability may be further increased with dedicated (central) thermal storage facilities which, depending on the storage size, may also allow for seasonal storage. Decentralized options, in contrast, may come without energy storage, which we refer to as direct heating. Other decentralized options are combined with thermal energy storage, referred to as storage heating. Such thermal storage may be either internal, such as in the case of electric thermal storage heaters, or external, i.e. connected to storage elements of standard water-based residential heating systems. Aside from such active thermal storage, which allows for controlled charging and discharging, there is also the options of passive thermal storage (not depicted in Figure 11). Here, thermal energy is stored in the building mass or the interior and released in a non-controlled way [see, for instance, 19, 20, 21.

Within these high-level categories, different technologies can be distinguished, among them various kinds of heat pumps $2^{2}$ and resistive heaters. Centralized power-to-heat approaches either draw on large-scale heat pumps that make use of geothermal (i.e. ground-sourced) energy, waste heat or brine, or on large electric boilers, often in the form of electrode boilers. In general, these options are also available in the group of decentralized storage heating options with external storage. Here, smaller-scale heat pumps are usually air- or ground-sourced. Resistive heating comes in the form of electric boilers or electric heating elements in boilers that are primarily fueled by some other form of primary energy. An example for the latter, which is also referred to as hybrid heating, is a water-based residential heating system with a boiler that is primarily fueled with natural gas and has an additional electric heating rod.

\footnotetext{
${ }^{2} \mathrm{~A}$ much-cited review on heat pumps is provided by Chua et al. 22, a more recent one by Fischer and Madani [23].
} 
Particularly in the heat pump literature, a related classification distinguishes between monovalent, mono-energetic, and bivalent approaches [23]. For example, a "monovalent" system consists only of a heat pump which is designed to cover the full heating energy demand in all hours of the year. In a "mono-energetic" system, a heat pump may be complemented by an electric heating element, which allows for smaller heat pump dimensioning. Yet the primary energy source - electricity - does not change. In contrast, "bivalent" systems draw on two heating options with different energy carriers. An example for the latter is a heat pump in combination with a fossil-fueled backup boiler.

More indirect ways of electric heating, such as the conversion of electricity to hydrogen or methane which may then fuel a boiler are not depicted in Figure 11 (and not considered further in this review). Likewise, Figure 1 focuses on residential space heating and does not include details on hot water provision. Yet most of the depicted options, with the exception of smart or "dumb" - electric thermal storage, may also be used to provide hot water.

Figure 2 illustrates the interconnection of different power-to-heat options with electricity and district heating networks. Centralized power-to-heat technologies draw electricity from the grid to generate heat, using either large-scale heat pumps or electric boilers. Heat energy is then transported to residential customers. In contrast, decentralized power-to-heat options do not make use of heating networks. Figure 2 also indicates that most power-to-heat options involve some energy storage capability ${ }^{3}$ From an energy system point of view, interactions between different kinds of heat and electricity storage technologies are of particular interest.

\footnotetext{
${ }^{3}$ Passive thermal energy storage related to the building mass is not even depicted in the Figure.
} 
Figure 2: Interconnections of power-to-heat options with electricity and district heating networks.

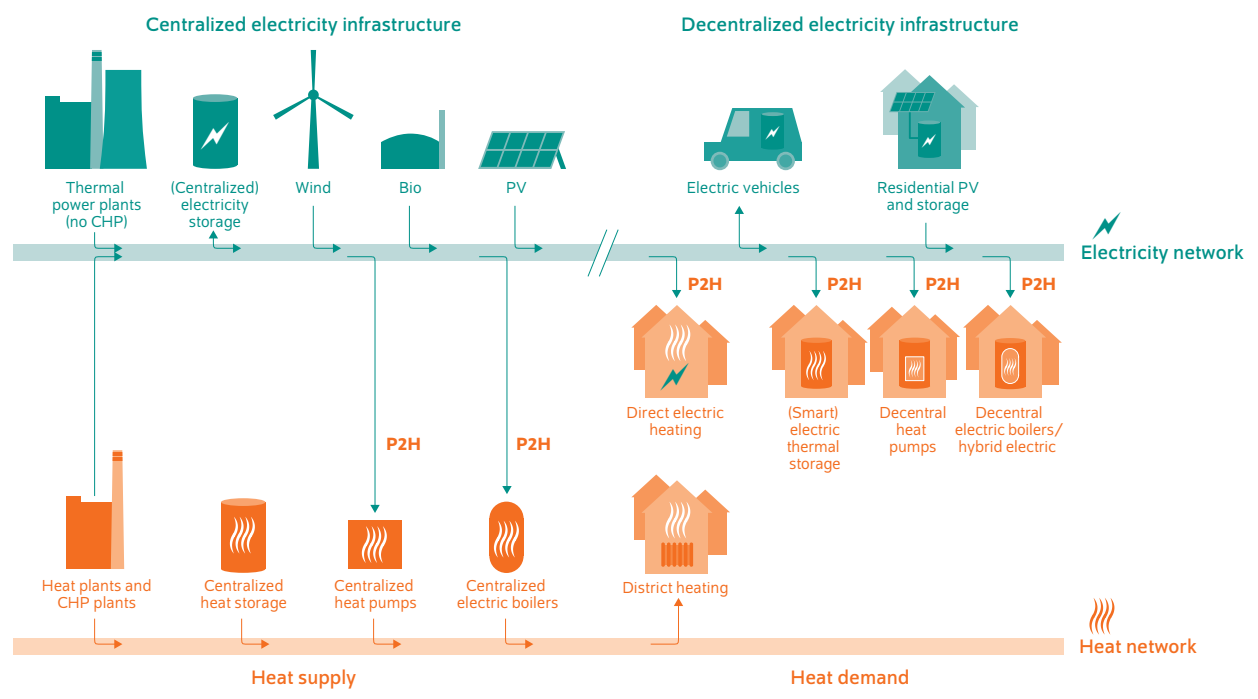

Source: Own illustration inspired by 24 .

\section{Methodology of this literature review}

We conducted a systematic literature search of model-based analyses in leading peer-reviewed journals of applied and economic energy research. To this end, we first screened the journals Applied Energy, Energy, Energy Economics, Energy Policy, and Renewable and Sustainable Energy Reviews for the keywords electric boiler, electric heating, electric thermal storage, heat pump, and power to heat. A search in the Web of Science Database resulted in a total number of 721 articles that appeared between 2007 and 2016 in these journals. The keyword heat pump lead to the most hits, and electric thermal storage to the least hits. The number of articles featuring one or more of the keywords substantially increases between 2007 and 2016 as Figure 3 illustrates. This may be interpreted as an increasing academic relevance of power-to-heat analyses. Yet the overall number of articles appearing in these journals also grows. The share of keyword articles in overall articles, thus, grew only from $1.2 \%$ in 2007 to $2.6 \%$ in 2016 . 
Within the retrieved articles, we carried out both a forward and backward search to identify relevant papers that the articles cite and are cited by. Thus, the scope of journals broadened to include further, rather technologically oriented, outlets, among others Energy and Buildings, Energy Conversion and Management or Journal of Cleaner Production, and a few studies from the gray ${ }^{4}$ literature. We took all papers into account that appeared, also online first, until January 1, 2017. Out of this sample, we focused on the 46 articles that are most relevant with respect to this review, and examined and compared these in depth.

Figure 3: Articles featuring keywords in journal sample

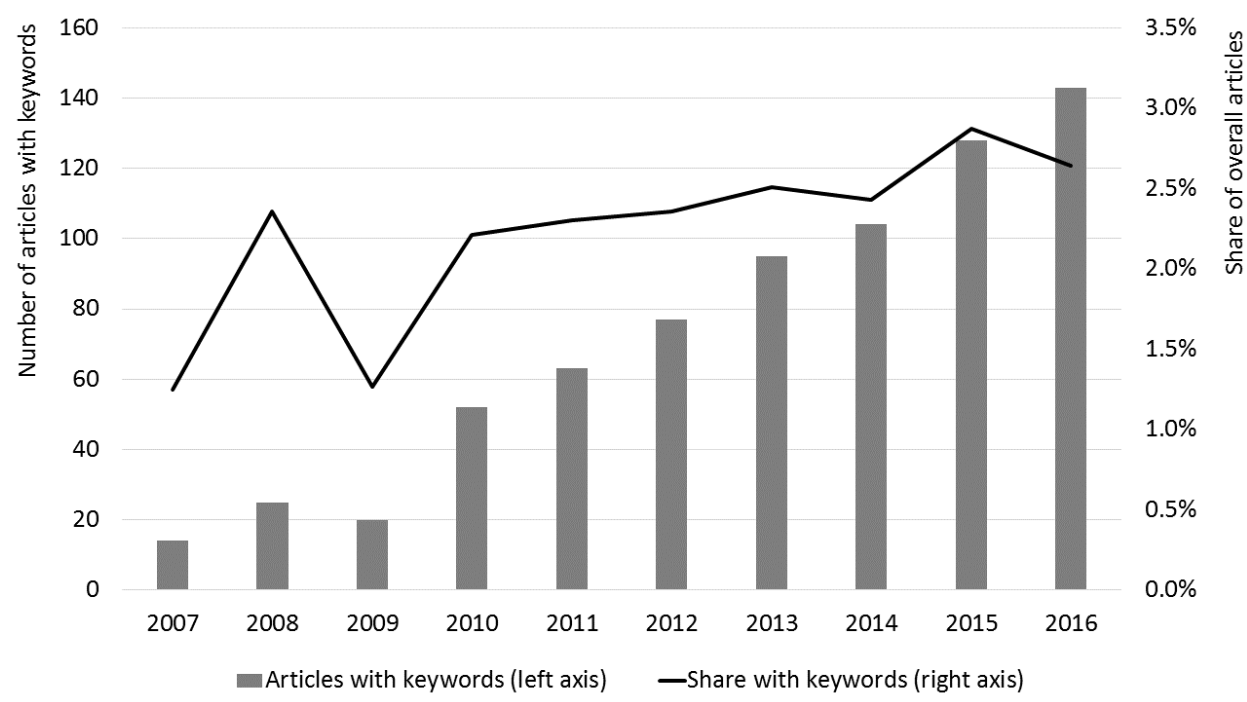

Source: Own calculations based on Web of Science data.

As we aim to provide a structured and detailed synthesis on the effects of power-to-heat technologies in power systems with renewable energy sources, the depth of this review must necessarily be traded off against the breadth: the main selection criteria were a traceable exposition and, for stringency of this review, a rather narrow focus on the techno-economic assessment of

\footnotetext{
${ }^{4}$ Some of these appeared as journal articles in 2017.
} 
residential power-to-heat in the context of renewable energy integration. For instance, the large bodies of literature on household heating behavior and optimal design of specific residential heating systems do not enter this review article. Evidently, there is some level of discretion; we do not claim to render a complete account of all published research on the topic. Nonetheless, we aim to present a broad account of important approaches and findings.

\section{Research scope: what research focused on so far}

The reviewed literature on residential power-to-heat for renewable energy integration is quite diverse. To provide some orientation, this section describes the temporal scope, geographical coverage as well as the analyzed technologies. See Table 1 for an overview.

\section{Table 1 about here}

Geographically, many applications focus on Northern and Western Europe. Within Europe, there is relatively broad evidence on the Nordic countries, specifically Denmark [25, 26, 27, 28, 29, 30, 31, 32, 33, 34, 35, 36]; many studies also focus on Belgium [37, 38, 39, 40, 41, 42, 43], Germany [44, 45, 46, 47, 48, 49, 50, 51, 52, 53, 54] as well as the UK [55, 56, 57, 58] and Ireland [59]. All countries have ambitious policies on long-term decarbonization targets, for the case of Denmark and Germany largely based on variable renewable energy sources, i.e. wind or solar photovoltaics (PV). Thus, research efforts are often directed toward managing the new electricity demand in the residential heating sector in a flexible way. Moreover, especially for Denmark, a developed district heating system calls for research efforts on specific de-carbonization potentials in this context.

Many studies have a long-term time horizon, often the years 2030 and 2050. Such long-term analyses allow the examination of scenarios with very high shares of renewables in an electricity and heating sector which will have adequately evolved instead of a legacy system shaped by current capacities. Accordingly, many papers assume a renewables share of $40 \%-60 \%$ or higher. 
However, a number of studies do either not explicitly state the share of renewable energy sources or - if they do - do not specify the technologies.

The range of heating technologies considered in the analyses is broad. Centralized heating may be provided by CHP plants, heat pumps, resistive heating or any combination of these technologies, often combined with heat storage. The papers differ greatly with respect to the level of technological detail; many applications represent technologies in a rather stylized way. Decentralized heating is likewise analyzed for a broad range of different technologies. Many analyses implement some stylized model of heat pumps or resistive electric heaters..$^{5}$ Hybrid heating technologies [explicitly considered in 47, 60] and smart electric thermal storage [SETS, explicitly considered in 55, 61, 57, 62, are not in the focus of most papers. A large share of models also employs some kind of decentralized heat storage to shift heating energy in time, often differentiated into passive and active storage.

Beyond electricity and heating, not many papers take further sectors into account; some applications explicitly model the mobility sector [55, 63. 64, 30, 33, 34, 36] or the cooling sector [63, 33. While interactions between the electricity and heating sectors can thus be conveniently focused on, broadening the scope to include further sectors, which are likewise subject to de-carbonization, could provide complementary insights.

Some model analyses comprise additional features such as the provision of control power [30, 46, 33] and an explicit consideration of behavioral incentives for households [42]. Also here, implementing more markets or objectives could render a more detailed picture of the dual challenge of decarbonizing the energy sector(s) and providing the necessary flexibility.

\footnotetext{
${ }^{5}$ The reviewed studies often do not differentiate and/or are not explicit on the difference between direct electric heating with fans or radiators and resistive storage heating, as categorized in Figure 1 We thus combined these approaches under the label resistive in column 7 of Table 1 .
} 


\section{Research methods and modeling approaches}

\subsection{Overview}

Most publications considered in this review are techno-economic partial equilibrium models of the energy sector. These models simulate the operation - some also investments - of a power system over a defined time interval. The objective often follows a cost-minimization logic; assuming perfect competition and foresight among market actors, results can be interpreted as market equilibrium outcomes. Many models are long-standing projects that evolved from electricity sector analyses into combined heat-and-electricitysystem analyses. Table 2 structures the reviewed papers according to the general method, the type of program, model name, time resolution, endogenous investments, and whether they provide explicit formulations for power-to-heat and heat storage equations.

\section{Table 2 about here}

An adequate additional treatment of the heat sector necessarily leads to new challenges in model formulation and computability. The majority of the reviewed articles are based on optimization, mostly cost minimization. Prominent examples are the models BALMOREL [25, 28, 29, 31, 64, 65], TIMES [48, 49, 50, 36], and energyPLAN [27, 33, 34, 63, 30. While the first two are cost minimization models, energyPLAN seeks to minimize consumption of fossil fuels. Other objectives comprise welfare maximization [66], the minimization of residual load variability [61] or some kind of flexibility maximization [38]. Most models apply linear programming (LP) or mixed-integer linear programming (MILP) to carry out the optimization.

Among the MILP models, many analyses focus on the optimal operation of the power system; integer variables allow for a greater level of realism in the dispatch of technologies. Few MILP models additionally consider optimal investment decisions [40, 43, 49, 50, which is computationally more convenient in LP approaches [44, 48, 28, 29, 31, 36, 52, 57, 59, 64. This is also reflected in the temporal resolution: combining a MILP with endogenous 
investment decisions tends to come at the cost of a limited number of time slices compared to the other works. While most of the reviewed models have an hourly time resolution, many do not cover all hours of the year, but make use of some time aggregation strategy. Few models have a sub-hourly resolution [56, 38, 66].

Some works do not rely on mathematical programming, but on heuristic methods [35, 45, 55, 56, 60, 67, 54, 53. Here, technologies are dispatched according to pre-specified hierarchies in case of renewable energy surplus or shortage for a number of scenarios with different data sets for demand, generation capacities or prices [55, 60, 67]. For instance, Barton et al. [55] apply, in case of shortages, a priority list which ranks storage discharging in the first place, followed by imports, dispatchable generation, and finally load shedding. In contrast, power surpluses are first used for storage charging, followed by fuel replacement in industry, power-to-heat instead of fuel-to-heat, and finally hydrogen production. In their greenfield simulation for Germany, Henning and Palzer [54, 53] design an iterative calibration process. They aim to find optimal capacities of different energy conversion technologies and energy efficiency measures in buildings. Also here, the operation of all conversion capacities follows a strict hierarchy favoring the use of renewable primary energies and higher conversion efficiencies. Costs are calculated subsequently in order to compare the simulations.

In addition, some papers explicitly devise specific mathematical formulations to represent heat pumps and heat storage in power system models. In the following, we discuss some common and some more elaborated approaches.

\subsection{Formulations for modeling heat pumps}

\subsubsection{Heat pumps: coefficient of performance}

Equation (1a) is the basic approach to represent electrical heat pumps. It assumes a constant relation between power input $P_{t}^{\text {input }}$ and heat output

$\dot{Q}_{t}^{\text {output }}$, the average coefficient of performance (COP) COP average, at any point in time $t$ [26, 27, 32, 36, 40, 41, 48, 55, 61, 64, 54, 27, 29]. This formulation is simple and allows convenient computability when there are 
negligible variations in the COP over time [36].

$$
P_{t}^{\text {input }}=\frac{\dot{Q}_{t}^{\text {output }}}{C O P^{\text {average }}} \forall t
$$

However, in reality the COP strongly depends on the temperature levels of the energy source, $T^{\text {source }}$, and sink, $T^{\text {sink }}$, as expressed by the CarnotCOP, $C O P^{\text {carnot }}=\frac{T^{\text {sink }}}{T^{\text {sink }}-T^{\text {source }}}$. A low source temperature as well as high sink temperature lead to a lower COP, which can cause a pronounced increase of the required power input or operational problems for heat pumps; for instance, in cold winters when the energy source is environmental air or when high supply temperatures are required. This may apply to centralized heat pumps feeding into conventional district heating networks, conventional radiator-based domestic distribution systems, or domestic hot water supply, which requires a certain minimum temperature to prevent legionella bacteria.

Formulation (1b) aims to capture this temperature dependence. Furthermore, a quality grade defined as $\eta:=\frac{C O P^{\text {real }}}{C O P^{c a r n o t}}$ can account for technical progress, where $C O P_{t}^{\text {carnot }}$ expresses the theoretically achievable COP according to the temperature conditions and $C O P_{t}^{\text {real }}$ the technically feasible COP. By 2014, such quality grades amounted to 0.24 to 0.45 [68].

$$
C O P_{t}^{\text {real }}=\eta \cdot C O P_{t}^{\text {carnot }}=\eta \cdot \frac{T_{t}^{\text {sink }}}{T_{t}^{\text {sink }}-T_{t}^{\text {source }}} \forall t
$$

Several reviewed models [25, 41, 43, 51] apply such formulations. Accounting for temperature dependence, relation (1a) transforms to $1 \mathrm{c}$.

$$
P_{t}^{\text {input }}=\frac{\dot{Q}_{t}^{\text {output }}}{C O P_{t}^{\text {real }}}=\frac{\dot{Q}_{t}^{\text {output }}}{\eta \cdot \frac{T_{t}^{\text {sink }}}{T_{t}^{\text {sink }}-T_{t}^{\text {source }}}} \forall t
$$

However, this formulation represents only an approximation; in reality, the supply temperature of a heating system, $T^{\text {sink}}$, is affected by the heat output $\dot{Q}^{\text {output }}$. Treating $C O P^{\text {real }}$ as an endogenous variable instead of an exogenous parameter leads to a non-linearity and, thus, to considerably higher computational efforts. Verhelst et al. [69] suggest to pre-calculate 
$C O P^{r e a l}$ as a parameter by assuming an expected value for $T^{\text {sink }}$ and given values for $T_{t}^{\text {source }}$, as done in all cases found here applying a temperature dependent COP. Alternatively, Heinen et al. [59] suggest assuming a linear relationship between the hourly COP and the ambient temperature $T^{a}$ according to $1 \mathrm{~d}$, , where empirical data determines the slope $m$. Furthermore, they fit this relation to a fixed $\mathrm{COP}$ as input, $C O P^{\text {input }}$, at a certain reference temperature of $7^{\circ} \mathrm{C}(280.15 \mathrm{~K})$.

$$
C O P_{t}\left(T^{a}\right)=m \cdot\left(T^{a}-280.15[K]\right)+C O P^{i n p u t}
$$

In order to capture higher efficiency in part-load mode and larger flexibility for load following of variable-speed heat pumps, Georges et al. [38] suggest a piece-wise linearization of the non-linear problem described by Verhelst et al. [69]. Salpakari et al. [70, who analyze the use of large-scale heat pumps in district heating networks, constrain heat pump use on the network's exogenous supply temperature and allow operation only below $90^{\circ} \mathrm{C}$. The COP is then treated as a constant parameter, which might be a justified assumption in the context of large-scale heat pumps with a stable heat energy source. Appendices A.1 and A.2 present a detailed formulation for both suggestions.

\subsubsection{Heat pumps with auxiliary electric boilers}

Several articles provide formulations for the use of auxiliary electric boilers (EB). For instance, Patteeuw et al. [41] augment the standard approach (1a) to formulation (1e and additionally distinguish between space heating $(\mathrm{SH})$ and domestic hot water (DHW) applications. Heat output is limited through further constraints on maximum power consumptions of the heat pump and electric boiler.

$$
P_{t}^{\text {input }}=\frac{\dot{Q}_{t}^{H P, S H}}{C O P^{S H}}+\frac{\dot{Q}_{t}^{E B, S H}}{\eta^{E B}}+\frac{\dot{Q}_{t}^{H P, D H W}}{C O P^{D H W}}+\frac{\dot{Q}_{t}^{E B, D H W}}{\eta^{E B}} \forall t
$$

Waite and Modi [67] integrate the performance of an auxiliary electric boiler into the COP pre-calculation. Its operation is triggered by help of a minimum design temperature; Appendix A.3 provides further details. To 
assure the installation of electric boiler capacities for peak loads, Hedegaard and Balyk [28] introduce constraint [1f]. The heat pump capacity share $c s^{H P}$ allows to freely adjust the ratio of heat pump and resistive heating capacity, $C^{H P}$ and $C^{E B}$, for which they suggest values between 0.72 to 0.82 .

$$
C^{H P}=\frac{c s^{H P}}{1-c s^{H P}} \cdot C^{E B}
$$

\subsection{Formulations for modeling heat storage}

Technologies for heat storage are subject to different layouts, depending on their specific use. They may require different minimum temperature levels, which can have an impact on storage losses or on whether heat pumps can be connected to the storage. For instance, domestic hot water storage generally requires higher temperature levels, due to hygienic standards, than buffer tanks for conventional individual space heating. Floor heating systems require even lower temperatures.

\subsubsection{Basic model}

Most models implement such different kinds of storage according to a standard formulation $(2)$, as found in [32, 59, 43, 27, 70, 54]. It comprises a law of motion 2a, with storage energy level $S$ and periodically charged and discharged energy $\dot{Q}^{C}$ and $\dot{Q}^{D}$, as well as a constraint on maximum storage energy $S^{\max } 2 \mathrm{~b}$. Some analyses specify the maximum storage capacity with the storage volume $V^{\max }$ in cubic meters as limiting parameter (2c), [59, 54], where $c_{p}, \rho$, and $\Delta T$ represent the specific heat capacity of water, its density, and temperature difference, respectively. Charging and discharging capacity constraints, 2d - 2e), are rather found for larger heat storages for

district heating. An alternative to energy levels is the use of temperature 
levels [47, 54].

$$
\begin{aligned}
S_{t+1} & =\left(1-l^{\text {stationary }}\right) \cdot S_{t}+\dot{Q}_{t}^{C}-l^{\text {dynamic }} \cdot \dot{Q}_{t}^{D} & & \forall t \\
S_{t} & \leq S^{\text {max }} & & \forall t \\
S^{\text {max }} & =c_{p} \cdot \rho \cdot \Delta T \cdot V^{\max } & & \forall t \\
\dot{Q}_{t}^{C} & \leq \dot{Q}^{C, \max } & & \forall t \\
\dot{Q}_{t}^{D} & \leq \dot{Q}^{D, \max } & & \forall t
\end{aligned}
$$

There are different ways to account for storage losses; either only stationary losses $l^{\text {stationary }}$ are considered [59, 43, 47, 27, 28], or stationary as well as dynamic losses $l^{\text {dynamic }}$ [54]. Patteeuw et al. [43] separate stationary heat losses in two parts: one proportional to the energy actually stored, the other one proportional to the storage size. In case of large heat storage devices for district heating, stationary losses are sometimes neglected [32, 70].

Alternatively, Henning and Palzer [54, 53] apply a differential equation for the storage energy content $3 \mathrm{a}$ ) and its stationary losses $(3 \mathrm{~b})$. The storage energy level is represented by the product of the storage's constant total heat capacity $C^{S}$ and its temperature change over time $\frac{d T^{S}}{d t}$. Stationary heat losses $\dot{Q}^{\text {loss }}$ depend on the temperature difference between storage and environment, $T^{S}-T^{a}$. Furthermore, they define a time lag $\tau$, which is rather long (180 days) for large centralized seasonal storage and small for decentralized short-term storage (72 hours), to replace the constant heat loss coefficient $U \cdot A$ consisting of the heat transfer coefficient $U$ resulting from the storage's insulation material and its exposed surface $A$.

$$
\begin{aligned}
C^{S} \cdot \frac{d T^{S}}{d t} & =l^{\text {dynamic }} \cdot \dot{Q}^{C}-\dot{Q}^{D}-\dot{Q}^{\text {loss }} \\
\dot{Q}_{\text {loss }} & =U \cdot A \cdot\left(T^{S}-T^{a}\right)=\frac{C^{S}}{\tau} \cdot\left(T^{S}-T^{a}\right)
\end{aligned}
$$

\subsubsection{Heat storage in district heating systems}

For district heating, different network levels can be considered. Nielsen et al. 32] apply the standard formulation 22 for two types of heat accumulation tanks in district heating: one on the transmission, the other on the 
distribution level with lower supply temperature. The former is connected to CHP plants and electric boilers with charging and discharging constraints according to $2 \mathrm{~d}$ ) and $2 \mathrm{e}$, the latter can be charged by the transmission network, heat pumps or electric boilers and has no charge or discharge constraints for storages. Salpakari et al. [70] additionally consider the storage capability of the network. They introduce a heat demand surplus, which allows for heat accumulation by increasing the storage level in the following time step.

\subsubsection{Passive heat storage}

Hedegaard et al. [27] apply the standard approach 22 to passive building mass storage and formulate the charging and discharging restrictions depending on a pre-specified temperature delta $\Delta T_{\text {passive }}$ for the building mass (4).

$$
\begin{array}{ll}
\dot{Q}_{t}^{C} \leq U \cdot A \cdot \Delta T_{\text {passive }} \cdot\left(1-\frac{S_{t-1}}{S^{\max }}\right) & \forall t \\
\dot{Q}_{t}^{D} \leq U \cdot A \cdot \Delta T_{\text {passive }} \cdot \frac{S_{t-1}}{S^{\max }} & \forall t
\end{array}
$$

Flexibility can also be provided by a room temperature target window. The formulation by Hedegaard et al. 28] comprises radiators and floor heating and accounts for another degree of flexibility provided by the passive energy storage capacity of the building mass. The temperature window is modeled by (5a) and $5 \mathrm{~b}$, where the actual room temperature $T_{t}^{I}$ is a variable that may deviate from a reference temperature $T^{I, r e f}$ within an interval $\left[T^{I, \min }, T^{I, \max }\right]$. A fraction $\frac{H S^{i n v}}{H S^{t o t}}$ of the residential building stock is equipped with control equipment to make use of this flexibility source. Equations (5c) to $5 \mathrm{f}$ ) model the influence of exogenous shocks, such as heat from inhabitants or electrical appliances $\dot{Q}_{t}^{P+A}$, ventilation $\dot{Q}_{t}^{V e n}$, ambient temperature $T_{t}^{a}$, and endogenous decisions on heating technologies $\dot{Q}_{t}^{H T}$. The lower the ambient temperature $T_{t}^{a}$, the more heat $\dot{Q}_{t}^{B O}$ escapes from the passive building storage (5e), thus reducing its temperature level $T_{t}^{B}$. In turn, more heat $\dot{Q}_{t}^{B I}$ is transferred from the interior into the building mass 
(5d). Parameters $A, C$ and $U$ render the exposed surface, heat capacity and heat transfer coefficient for inner masses (I) and building mass (B).

$$
\begin{array}{rlrl}
T_{t}^{I} & \geq T^{I, r e f}+\left(T^{I, \text { min }}-T^{I, r e f}\right) \cdot \frac{H S^{\text {inv }}}{H S^{\text {tot }}} & & \forall t \\
T_{t}^{I} & \leq T^{I, r e f}+\left(T^{I, \text { max }}-T^{I, r e f}\right) \cdot \frac{H S^{\text {inv }}}{H S^{\text {tot }}} & & \forall t \\
T_{t+1}^{I} & =T_{t}^{I}+\frac{\dot{Q}_{t}^{H T}+\dot{Q}_{t}^{P+A}+\dot{Q}_{t}^{S, l o s s}-\dot{Q}_{t}^{\text {Ven }}-\dot{Q}_{t}^{I B}}{C^{I} \cdot A} & & \forall t \\
\dot{Q}_{t}^{I B} & =U^{I B} \cdot A \cdot\left(T_{t}^{I}-T_{t}^{B}\right) & & \forall t \\
\dot{Q}_{t}^{B O} & =U^{B O} \cdot A \cdot\left(T_{t}^{B}-T_{t}^{a}\right) & \forall t \\
T_{t+1}^{B} & =T_{t}^{B}+\frac{\dot{Q}_{t}^{I B}-\dot{Q}_{t}^{B O}}{C^{B} \cdot A} & & \forall t
\end{array}
$$

Chen et al. [61, Patteeuw et al. 41], and Papaefthymiou et al. [51] also apply this concept. Specifically, the latter synthesize a virtual electric storage in a power system based on the aggregated building mass equipped with heat pumps. To this end, they derive room temperatures from a building simulation and use those as reference room temperatures $T_{t}^{r e f}$ in an electricity market model without building mass storage. In a second step, they introduce a comfortable room temperature window (6b), taking into account passive building mass storage. The temperature delta $\Delta T_{t}$ between $T_{t}^{r e f}$ and $T_{t}$ in the second calculation is limited through a linear relationship with the power input delta $\Delta P_{t}$ in equation (6a) and its capacity constraint (6c). The demand response operation of heat pumps is thus modeled as equivalent energy storage. This two-step approach offers two advantages: (i) advanced models for thermal behavior of buildings can be applied as the reference operation is computed separately, and (ii) linear models can be used to incorporate this type of demand response, which is defined as deviation from 
the reference case, allowing the use of typical dispatch models.

$$
\begin{aligned}
\Delta T_{t} & =\frac{1}{C^{\text {tot }} \cdot C O P_{t}} \cdot \Delta P_{t} & & \forall t \\
T_{t}^{\text {min }} & \leq T_{t} \leq T_{t}^{\max } & & \forall t \\
0 & \leq P_{t}^{\text {ref }}+\Delta P_{t} \leq P^{\max } & & \forall t
\end{aligned}
$$

\subsubsection{State-space model}

With varying co-authors, Patteeuw developed a state-space representation of residential heating demand that can be integrated into economic system optimization models [39, 40, 41, 42, 43. The vector $T_{s, t}$ captures the temperature state of the indoor air, floor, walls and the roof for each building (class) $s$ in period $t$. Temperatures in the next period depend on the temperatures in the current period, where thermal conductances and capacities are summarized in matrix $A$. Moreover, vector $Q_{s, t}$ contains all heat inputs to the system, consisting of solar irradiation, internal heat gains, outside and ground temperature as well as heat gains from heating devices, transmitted with factors summarized in matrix $B$. Heat dynamics are thus given by 7 .

$$
T_{s, t+1}=A T_{s, t}+B Q_{s, t}
$$

Together with constraints on the thermal comfort level $T^{\text {min }} \leq T_{s, t}^{a i r} \leq T^{\max }$, where $T_{s, t}^{a i r}$ is an element of vector $T_{s, t}$, this set of linear equations can be plugged into dispatch and investment optimization models of the energy system to capture relevant interactions.

\section{Research questions and findings}

\subsection{Overview}

The reviewed articles on power-to-heat not only differ with respect to technologies, research scopes, and methodologies, but also aim to answer distinct research questions. Most papers provide evidence on the potential 
of residential power-to-heat options for the system integration of variable renewable energy sources. A closely related research focus is the contribution to decarbonizing the energy sector. Cost effectiveness is another research focus and an important criterion to judge different technologies or policies; in fact, the majority of analyses are optimization exercises aiming to reduce overall system costs of operation and, partly, investments. It is difficult though to disentangle these three objectives because they mutually influence each other. For instance, cost effectiveness can be seen both as a primary goal under constraints on renewable energy use or decarbonization and as a criterion to compare different scenarios of renewable energy integration. Beyond that, some analyses investigate the structure of heat supply, additional electricity demand of power-to-heat applications, and the impact on power prices. Moreover, some of the articles put emphasis on the development and presentation of a model or particular model features.

\section{Table 3 about here}

Table 3 summarizes the research questions. It indicates for all selected papers whether there is a distinct emphasis on particular research questions; parentheses indicate a secondary focus.

\subsection{Cost effectiveness}

A common finding of many reviewed articles is that power-to-heat applications have the potential to cost-effectively integrate high shares of variable renewable electricity into the energy system. Cost reductions are driven by (i) the substitution of fossil fuels [27, 29, 35, 36, 51, 59, 52, 63, 37, (ii) better use of capital invested in renewable assets by means of reduced curtailment [59, 60, 61, 66, 67, 71, 43], (iii) less need for costly auxiliary technologies such as peak-load capacity [29, 40] or power storage [64], (iv) more efficient operation of thermal power plants because of less need for cycling and part-load operation [58, 42], and (v) the use of existing district heating infrastructure [31, 46, 61, 66, 54, 53. 
For instance, Teng et al. [58] conclude from long-term analyses for the United Kingdom that flexible heat pumps could significantly lower the costs for integrating renewables and reducing carbon emission, particularly if heat pumps can provide frequency response. This is, among other factors, driven by improved efficiency of thermal generators due smoother residual load and less need to run generators in part-load mode. Overall savings in renewable integration costs facilitated by flexible heat pumps are composed of lower costs for both backup and balancing (CAPEX and OPEX) and amount up to 6.5 Pound Sterling per MWh in a 2050 scenario. In an stylized Belgian setting, Patteeuw et al. provide a related finding [42].

With different co-authors, Hedegaard [27, 29] simulates the Danish energy system with complementary models. Here, heat pumps and passive heat storage are found to be low-cost options for reducing renewable curtailment and fossil fuel consumption. In 2030, decentralized heat pumps could save more than $10 \%$ of system costs compared to a reference without heat pumps [29]. Yet additional active heat storage decreases overall system costs decrease not at all [27] or only to a minor extent [29] as this would incur relatively large capital costs. This finding is corroborated by Patteeuw and Helsen [43] for Belgium who find that high investment costs and losses make active thermal storage inefficient. Likewise, Papaefthymiou et al. [51] find significant cost reductions when large-scale deployment of decentralized heat pumps in Germany is combined with passive thermal storage in the building mass. The analysis shows a growing potential for system cost savings with higher renewables penetration, indicating a future key role for the flexibility provided by passive thermal storage.

Taking on a broader perspective, Conolly et al. 63] point to a general transformation of the cost structure of energy systems, that is, a shift from fuel to investment costs. Comparing scenarios with very high renewable shares up to $100 \%$ and more fossil-based reference scenarios, several analyses show that renewable-dominated systems that make use of power-to-heat may incur equal or only slightly higher total costs while achieving larger emission reductions [33, 63, 54, 53]. Yet external costs of fossil fuel use are often not properly considered in such analyses. 
Comparative analyses on sector coupling conclude that it is first and foremost cost-effective to couple the power and heat sectors [30, 52, 64]. Schaber et al. [52] argue that cost savings related to fuel consumption would be similar for coupling the power and hydrogen sectors; however, this would require higher investment costs compared to power-heat-coupling. Likewise, Mathiesen and Lund [30] concede that some types of electrolysers could supply larger operational flexibility than heat pumps, but are at the same time considerably less efficient and hence uneconomical. Kiviluoma and Meibom [64] find that power-to-heat options coupled with thermal storage can be more cost-effective than the grid integration of electric vehicles - yet both options combined would be even better.

\subsection{Integration of variable renewable electricity}

To be precise, we understand "renewable energy integration" as a higher utilization of renewable energy sources to meet final energy demand. Powerto-heat can contribute to such integration with respect to both a better utilization of existing assets and additional renewable capacity expansion. In particular, power-to-heat allows making better use of temporary renewable surplus generation. This may already apply (i) without the use of additional heat storage [67, 40], particularly in case district heating systems can be used [33, 29, 45, 46, 66, 70]. Utilization of renewable surpluses generally improves if (ii) additional active or passive heat storage is available [34, 52, 61, 48, 51, 37, 60, 40, 42, 63, 53, 64], or if (iii) flexible fuel switching facilitated by hybrid heating systems enables "virtual" energy storage [59, 47].

Patteeuw and co-authors highlight the value of additional flexibility for renewable integration in studies for Belgium: they find substantially reduced renewable curtailment in case of system-optimal use of decentralized heat pumps [43], in particular compared to inflexible heat pump use [40]. This allows reducing curtailment by around 50\%; participating households, however, would have to receive appropriate incentives [42].

Hedegaard et al. [29] bring forward that the large-scale installation of heat pumps is a key strategy for increasing the share of wind power in total Danish primary energy consumption. Investments into additional auxiliary 
control equipment, which would render individual heat pumps more flexible, are found to be socio-economically feasible, yet related benefits are only moderate. Further papers on Denmark apply the energy system model energyPLAN, which explicitly targets maximizing renewable energy use: Mathiesen and Lund [30] conclude that centralized heat pumps are by far the most suitable technology to save non-renewable primary fuels by 2030. Combined with electric boilers, centralized heat pumps help minimizing excess wind electricity. Hedegaard et al. 27] derive similar conclusions for a 2020 setting with a $50 \%$ wind power share. They identify reduced excess electricity production by somewhat below $10 \%$ in case of a large-scale roll-out of decentralized heat pumps. While active heat storage only moderately increases this figure, passive thermal storage in buildings reduces curtailment up to almost 20\%. In two studies on municipal energy systems [33, 34], Østergaard analogously derives a key role for centralized heat pumps in a renewabledominated future system.

The literature provides similar findings for other energy systems: Kiviluoma and Meibom [64], for Finland, find that power-to-heat options with active storage lead to a higher optimal wind power capacity. Likewise, Waite and Modi [67], for New York City, argue that a mass roll-out of individual heat pumps enables greater expansion of wind power. While the overall utilization of wind power increases, the share of wind generation to cover conventional power demand decreases. In a study for Beijing in 2020, Chen et al. 61] determine an effective reduction of wind power curtailment through both the large-scale roll out of heat pumps and SETS. Under $20 \%$ wind penetration, passive heat storage suffices; with $40 \%$ wind, however, SETS are more effective to reduce wind curtailment due to additionally available active heat storage capacity. Also for the Beijing region, Liu et al. [66] determine a reduction in wind power curtailment from $7.5 \%$ to below $2 \%$ for an optimal roll-out of centralized electric boilers. Hughes [62] simulates the potential of SETS with different storage sizes for wind power integration in a Canadian island setting. Here, increasing numbers of SETS systems as well as increasing storage capacities of SETS reduce wind power surpluses, but may also diminish heating security due to (exogenously) limited wind power 
availability.

Two papers devise a framework of fully renewable electricity supply: For Helsinki, Salpakari et al. [70] conclude on a significant reduction of excess electricity from different centralized power-to-heat options - excess decreases from $40 \%$ to about $10 \%$; the effect of additional thermal storage would be comparatively small. Pensini et al. 60] study the Pennsylvania-New JerseyMaryland (PJM) market area in the US. Here, excess electricity could be reduced by up to almost $90 \%$ if decentralized resistive heaters with active storage were installed. A system with centralized heat pumps and active thermal storage could reduce curtailment by only $50 \%$, however at considerably lower costs.

\subsection{Decarbonization}

Power-to-heat contributes to decarbonization if the substitution of fossil fuels for heating yields greater emission reductions than a potential emissions increase due to additional electricity demand [cp. also 72]. As reduced $\mathrm{CO}_{2}$ emissions are a corollary of a higher utilization of renewable energy sources, in principle, the same channels as laid out in Section 6.3 apply. Beyond that, some of the reviewed works explicitly derive figures. Specifically, ceteris paribus analyses that compare optimal system configurations (or paths) with and without particular power-to-heat technologies can shed light on decarbonization potentials.

For Beijing, Chen et al. [61] conclude on significant emission reductions, around $30-40 \%$, in a scenario where heat pumps partly displace coal boilers. Similarly, Waite and Modi [67], for New York City, assess $\mathrm{CO}_{2}$ reductions up to about $10 \%$ when heat pumps replace $20 \%$ of gas-fired boilers. In an analysis for Finland in 2035, Kiviluoma and Meibom [64] conclude on a 30\% emission reduction if heat pumps, electric boilers, and thermal energy storage are available compared to a baseline without these options. Likewise, studies for Belgium derive a substantial decarbonization potential for households. Here, decentralized heat pumps can save between about 10 and $75 \% \mathrm{CO}_{2}$ emissions compared to a baseline with natural gas-fired boilers, depending on the electricity mix [43]. Focusing on consumer behaviour, it was found that 
emission savings are up to $7 \%$ higher if households do not behave myopically, but dispatch their heat pumps in a system-optimal way [42].

Several analyses find additional decarbonization benefits related to increased power-to-heat flexibility, facilitated in particular by heat storage 6 Patteeuw et al. [40] underline that $\mathrm{CO}_{2}$ emissions for residential heating would decrease by between $15 \%$ and $55 \%$ after replacing gas-fired boilers by heat pumps in a Belgian setting with $40 \%$ wind and PV; an additional flexible use of these heat pumps would contribute another $15 \%$ to decarbonization. Likewise, Papaefthymiou et al. [51] determine notable $\mathrm{CO}_{2}$ savings if a given residential heat pump fleet is operated flexibly, enabled by passive storage. In contrast, Hedegaard and Münster [29] see only minor carbon benefits from flexible operation of power-to-heat devices. In a study for Denmark in 2030, they assess by about $40 \%$ lower $\mathrm{CO}_{2}$ emissions from large-scale heat pump deployment compared to a case without heat pumps. Additional flexibility from active or passive heat storage would only add a minor $2 \%$ to this figure. A possible emission increase due to thermal losses of active heat storage is highlighted by Chen et al. 61] who analyze the roll-out of SETS in Beijing in 2020. Analogously, Patteeuw and Helsen [43] argue that thermal energy storage could increase $\mathrm{CO}_{2}$ emissions of buildings due to higher energy demand arising from standby losses; for space heating, the storage capacity of the building mass would be sufficient.

Focusing on system services, Böttger et al. [46], for Germany, determine lower $\mathrm{CO}_{2}$ emissions, by $0.4-0.9 \%$, when centralized electric boilers participate in control power supply. Teng et al. [58] provide a similar finding for the UK: they conclude that the flexibility provided by heat pumps enables substantial $\mathrm{CO}_{2}$ emission reductions, up to $30 \%$, compared to a case with non-flexible heat pumps, particularly if heat pumps can provide frequency response.

\footnotetext{
${ }^{6}$ For emission effects of other thermal energy storage applications see 73 .
} 


\subsection{Power prices and electricity demand for power-to-heat}

Some papers explicitly consider the impact of power-to-heat applications on electricity prices. If electricity substitutes other fuels in residential heating, demand for electric power increases [37, 55, 63, 56, 65, 50, 39, 40, 52, and, in turn, power prices may rise [37, 44, 65]. However, the high efficiency of heat pumps and the flexibility of new loads may counteract this effect to some extent.

Arteconi et al. 37] and Patteeuw et al. 39] explicitly address this effect in studies for Belgium, loosely calibrated to 2030 parameter projections. They conclude that the additional electricity demand for residential heat can cause substantial price spikes if inflexible, that is, if it must be served within the hour of demand. If active and passive heat storage is available for a quarter to half of this load, price spikes largely vanish, also leading to a reduced consumer bill; the additional price effect of an entirely flexible demand is rather small.

For the United Kingdom, Cooper et al. [56] argue that peak demand, defined as the minute with highest residual load, increases substantially in case of a large-scale roll-out of heat pumps. In 2030 scenarios without thermal storage except for the building mass, heat pumps in $80 \%$ of all buildings increase peak demand by about $30 \%$, compared to a baseline without heat pumps. However, a more moderate heat pump roll-out, their flexible operation, and both active and passive thermal storage can mitigate the increase to between 7 and 16\%. Likewise, Barton et al. [55] state that the additional peak load from heat pump electricity demand can be significantly reduced through flexible operation.

For Germany, Bauermann et al. 44] argue that heat pumps would only have a minor impact on power prices. Rather, they contribute to the power system's flexibility and, thus, help smoothing prices. In a counterfactual analysis for Norway, whose power system is dominated by hydro power, Kirkerud et al. [65] come to a related conclusion: currently installed auxiliary electric boilers in district heating networks have a significant upward impact on power prices in a wet year but little impact in a dry year, where they are used only to a minor extent. Conversely, if heat pumps or electric boilers 
substitute fossil fuels in decentralized residential heating, price impacts in dry years would be substantial.

\subsection{Structure of heat supply}

Studies on the structure of heat supply shed light on trade-offs between power-to-heat technologies [25, 33, 30]. Specifically, several analyses endogenously determine an optimal capacity mix of heating technologies [57, 59, 64, 43, 60, 36, 31, 48, 50, 44. Most papers see a future central role for heat pumps in low-carbon energy systems.

Dodds [57] analyzes the residential heat supply in the United Kingdom until 2050 under an overall 80\% decarbonization constraint. Until 2030, natural gas-fired boilers dominate; by 2050, decentralized heat pumps prevail and supply around $60 \%$ of residential heat. Specifically, a range of boundary conditions restrict heat pump deployment below the economic optimum. These comprise consumer preferences, space requirements, the presence of existing long-lived infrastructures, and regulatory inertia favoring incumbent technologies. Likewise, Petrović and Karlsson [36] see a central role for ground-sourced heat pumps in Denmark by 2050, however also constrained by the available ground area. Other analyses for different Nordic countries also include a future switch from natural gas to heat pumps and to a lesser extents to electric boilers [64] for decentralized heat supply, alongside continued district heating [31]. In a study on the district heating system of Copenhagen in 2025, Bach et al. 25] stress a complementarity between heat pumps and CHP plants: while the former produce heat in hours with low electricity prices, the latter conversely do so in high-price hours. In any case, heat pumps would replace some CHP production; moreover, their full-load hours would be highest when connected to the heat distribution grid.

For Belgium, Patteeuw and Helsen [43] provide more differentiated results. Specifically, the optimal technology mix of decentralized heat technologies differs by house types. Especially rural and detached buildings rely on heat pumps with complementary electric resistive heaters. Active heat storage is never part of the optimal supply mix. Heinen et al. [59], in their study for Ireland in 2030, also stress that active heat storage is deployed 
to a larger extent only in a setting where the heating system is based on heat pumps and resistive heating to avoid price spikes. Otherwise, a mix of heat pumps or resistive heaters with natural gas boilers (and withoput active storage) would efficiently achieve the same goal.

Fehrenbach et al. [48], for Germany, model a phase-out of oil fired boilers until 2050, which are replaced by a renewable technology mix including heat pumps. In this context, higher fossil fuel and $\mathrm{CO}_{2}$-prices favor heat pumps and efficiency measures over micro-CHP; lower prices favor the expansion of micro-CHP. In all scenarios, heat pumps and, to a somewhat lesser extent, thermal storage provide a significant greater load management potential than micro-CHP. These findings are in line with those by Merkel et al. [50] who also identify a strong impact of $\mathrm{CO}_{2}$ and fuel prices on micro-CHP deployment, and identify high RES targets as drivers for heat pumps. In contrast, Bauermann et al. 44] conclude for Germany that, despite major differences in scenarios, natural gas heating systems would keep their leading market position.

\subsection{Implications of methodology choice}

Besides deriving results on the potentials of power-to-heat, several of the reviewed articles distinctly discuss model formulations [44, 46, 57, 47, 38, 28, 59, 54, 66, 49, 31, 32, 51, 39, 41, 42, 43, 36, 70. Section 5 discusses some specific examples in more detail.

Comparing results for heat pumps either modeled with a fixed or a temperature-dependent COP does not yield unanimous conclusions: Petrović and Karlsson [36] argue that the assumptions of a fixed COP underestimates costs and $\mathrm{CO}_{2}$ emissions substantially, especially for air-sourced heat pumps, due to underrated electricity demand at low ambient temperatures. On the contrary, Bach et al. 25] bring forward that the application of a variable or fixed COP for centralized heat pumps has little influence on model results. However, it is important to distinguish for centralized heat pumps to which level of the district heating network they supply. For the distribution level, they are subject to a lower supply (i.e., sink) temperature and, thus, exhibit a substantially higher COP than heat pumps on the transmission level. 
Patteeuw et al. 42] compare different approaches of modeling demandside behavior; specifically, household incentives to use their flexible heat pumps in a system-friendly manner. They conclude that time-of-use pricing yields poor incentives for system-friendly behavior because a large fleet of heat pumps does not anticipate its impact on dispatch. If price forecasts that take into account an integrated and optimized dispatch are communicated to households, their heat pump dispatch is much more system-friendly.

\section{Conclusions}

Achieving medium- and long-term climate targets calls for decarbonization not only of electricity generation, but also of the space heating sector. At the same time, the power system integration of variable wind and solar energy sources requires additional flexibility. A flexible coupling of power and heat sectors appears to be a promising strategy to address both of these challenges. Several power-to-heat technologies are available that may contribute to both decarbonizing heat supply and, if sufficiently flexible, integrating variable renewable electricity.

The literature provides a rich set of analytical approaches how to model power-to-heat technologies in power systems. While numerical findings are idiosyncratic to place, time, and assumptions of costs, policies, and technology availability, a synthesis generally suggests that power-to-heat can cost-effectively contribute to renewable energy integration. This is driven by the substitution of costly fossil fuels, reduced need for expensive peak load technology, more efficient operation of thermal plants, synergies of using existing district heating infrastructures, and a better use of invested capital from reduced curtailment. In turn, reduced curtailment corresponds to a better integration and higher utilization of renewable energy; in a dynamic perspective, flexible power demand for heating also allows further expanding variable renewable generators. Consequently, overall $\mathrm{CO}_{2}$ emissions may decrease. The effect of additional heat storage on carbon emissions is not clear and depends on the power plant portfolio.

Power-to-heat technologies can have positive impacts in the above do- 
mains. Specifically, the literature sees a central role for heat pumps, be it decentralized or connected to district heating grids. Electric boilers are likewise identified as a relevant - and often supplementary - option. In contrast, smart electric thermal storage hardly plays a role in the reviewed analyses. Passive heat storage in well insulated buildings can help to tap additional low-cost flexibility potentials. Yet model formulations often appear to be rather stylized and may not take the residents' behavior properly into account. The reviewed papers do not come to unanimous conclusions of the future relevance of active heat storage; most analyses conclude on a rather subordinate role. If power is used for heating, electricity demand and power prices ceteris paribus rises. This does, however, not have to result in extreme price spikes, if the heating sector is sufficiently flexible, for example enabled by flexible operation of power-to-heat options or thermal storage.

While there is a growing body of evidence on the future role of powerto-heat technologies in low-carbon energy systems, there is much scope for further insights. First, our analysis of the reviewed articles' scope indicates that most papers focus on European case studies - complementary evidence on Asia, the Americas, and Africa, would be desirable. It would be valuable to also analyze power-to-heat options in developing countries, where heat and power system infrastructures are often less developed compared to most analyses reviewed here. Second, while some of the articles explicitly consider other sectors of the energy system, like mobility, broadening the scope of sector coupling could provide further valuable insights on alternative or complementary decarbonization and flexibility potentials. Specifically, combined analyses of power-to-heat and other options referred to as power-to- $x$, for instance electrolytic hydrogen generation, may shed light on the comparative attractiveness of power-to-heat. In this context, it would further be desirable to include other, non-electric renewable heating options. Third, our methodological survey shows that most reviewed papers are based on optimization models. Future research could enrich the focus by explicitly considering behavior and incentives of involved parties, be it consumers, regulators or policymakers. 


\section{Acknowledgements}

The authors thank Ciara O'Dwyer, Oliver Ruhnau, and the participants of the May 2017 Strommarkttreffen TechTalk seminar at DIW Berlin for valuable comments. Special thanks to Roman Wilhelm for his kind assistance concerning Figure 2. This work was carried out within the European Union's Horizon 2020 research project RealValue (grant agreement No 646116). Andreas Bloess kindly acknowledges financial support by the Friedrich Naumann Foundation for Freedom with funds provided by the German Federal Ministry of Education and Research. 
Table 1: Research scope

\begin{tabular}{|c|c|c|c|c|c|c|c|c|c|c|c|}
\hline \multirow[b]{2}{*}{ Paper } & & \multirow[b]{2}{*}{$\begin{array}{l}\text { Geogr. } \\
\text { scope }\end{array}$} & \multirow[b]{2}{*}{$\begin{array}{l}\text { Time } \\
\text { horizon }\end{array}$} & \multirow[b]{2}{*}{$\begin{array}{l}\text { RES } \\
\text { shares }\end{array}$} & \multicolumn{2}{|c|}{ Centralized heat } & \multicolumn{3}{|c|}{ Decentralized heat } & \multirow[b]{2}{*}{$\begin{array}{l}\text { Other } \\
\text { sectors }\end{array}$} & \multirow[b]{2}{*}{$\begin{array}{l}\text { Other } \\
\text { features }\end{array}$} \\
\hline & & & & & $\begin{array}{l}\text { Resistive/ } \\
\text { heat } \\
\text { pumps/ } \\
\text { CHP }\end{array}$ & $\begin{array}{l}\text { Heat } \\
\text { stor- } \\
\text { age }\end{array}$ & $\begin{array}{l}\text { Resis- } \\
\text { tive/ } \\
\text { hybrid/ } \\
\text { SETS }\end{array}$ & $\begin{array}{l}\text { Heat } \\
\text { pumps / } \\
\text { mCHP }\end{array}$ & $\begin{array}{l}\text { Heat } \\
\text { storage }\end{array}$ & & \\
\hline $\begin{array}{l}\text { Arteconi et } \\
\text { al. } 2016\end{array}$ & 37 & $\begin{array}{l}\text { Belgium } \\
\text { (styl- } \\
\text { ized) }\end{array}$ & 2030 & $30 \%$ & $-/-/-$ & - & $\checkmark /-/-$ & $\checkmark /-$ & $\begin{array}{l}\text { passive, } \\
\text { DHW }\end{array}$ & - & - \\
\hline $\begin{array}{l}\text { Bach et } \\
\text { al. } 2016\end{array}$ & 25 & $\begin{array}{l}\text { Copen- } \\
\text { hagen }\end{array}$ & 2013,2015 & $\mathrm{n} / \mathrm{s}$ & $-/ \mathfrak{J} / \mathfrak{J}$ & $\checkmark$ & $-/-/-$ & $-/-$ & - & - & - \\
\hline $\begin{array}{l}\text { Barton et } \\
\text { al. } 2013\end{array}$ & 55 & UK & $2010-2050$ & $\mathrm{n} / \mathrm{s}$ & $-/-/-$ & - & $\checkmark /-/ \checkmark$ & $\sqrt{ } / \mathfrak{d}$ & $\begin{array}{l}\text { passive, } \\
\text { DHW, } \\
\text { SETS }\end{array}$ & vehicles & - \\
\hline $\begin{array}{l}\text { Bauermann et } \\
\text { al. } 2014\end{array}$ & 44] & Germany & $2010-2050$ & $\mathrm{n} / \mathrm{s}$ & $-/-/ \downarrow$ & - & $-/-/-$ & $\checkmark /-$ & - & - & - \\
\hline Blarke 2012 & $26]$ & $\begin{array}{l}\text { West } \\
\text { Denmark }\end{array}$ & $\begin{array}{l}\text { 2003-2010 } \\
\text { (scenarios) }\end{array}$ & $20 \%$ & $\checkmark / \checkmark / J$ & $\checkmark$ & $-/-/-$ & $-/-$ & - & $\begin{array}{l}\text { (cool- } \\
\text { ing) }\end{array}$ & - \\
\hline $\begin{array}{l}\text { Böttger et } \\
\text { al. } 2014\end{array}$ & 45] & Germany & $2015-2030$ & $\mathrm{n} / \mathrm{s}$ & $\checkmark /-/-$ & - & $-/-/-$ & $-/-$ & - & - & \\
\hline $\begin{array}{l}\text { Böttger et } \\
\text { al. } 2015\end{array}$ & 46] & Germany & 2012,2025 & $23 \%, 54 \%$ & $\sqrt{ } /-/ \mathfrak{d}$ & $\checkmark$ & $-/-/-$ & $-/-$ & - & - & $\begin{array}{l}\text { control } \\
\text { power }\end{array}$ \\
\hline $\begin{array}{l}\text { Chen et } \\
\text { al. } 2014\end{array}$ & 61 & Beijing & $2009-2020$ & $0,20,40 \%$ & $-/-/(\boldsymbol{J})$ & - & $\checkmark /-/ \checkmark$ & $\checkmark /-$ & $\begin{array}{l}\text { passive, } \\
\text { SETS }\end{array}$ & - & - \\
\hline $\begin{array}{l}\text { Connolly et } \\
\text { al. } 2016\end{array}$ & 63] & EU-28 & 2050 & $\begin{array}{l}\text { up to } \\
100 \%\end{array}$ & $\checkmark / \mathfrak{J}$ & $\checkmark$ & $\checkmark /-/-$ & $\checkmark / J$ & - & $\begin{array}{l}\text { vehicles, } \\
\text { cooling }\end{array}$ & - \\
\hline $\begin{array}{l}\text { Cooper et } \\
\text { al. } 2016\end{array}$ & 56 & UK & $\begin{array}{l}2020 \mathrm{~s}, \\
2030 \mathrm{~s}, \\
2050 \mathrm{~s}\end{array}$ & $\begin{array}{l}14,25 \\
38 \%\end{array}$ & $-/-/-$ & - & $-/-/-$ & $\checkmark /-$ & $\begin{array}{l}\text { passive, } \\
\text { DHW, } \\
\text { active }\end{array}$ & - & - \\
\hline Dodds 2014 & 57 & UK & $2010-2050$ & $\mathrm{n} / \mathrm{s}$ & $-/-/ \checkmark$ & - & $\checkmark /-/ \mathfrak{S}$ & $\checkmark / \sqrt{ }$ & - & - & - \\
\hline $\begin{array}{l}\text { Ehrlich et } \\
\text { al. } 2015\end{array}$ & 47] & Germany & 2020 & $\mathrm{n} / \mathrm{s}$ & $-/-/-$ & - & $-/ \mathfrak{J} /-$ & $-/-$ & active & - & - \\
\hline $\begin{array}{l}\text { Fehrenbach et } \\
\text { al. } 2014\end{array}$ & 48] & Germany & $2010-2050$ & endog. & $-/-/ \checkmark$ & - & $-/-/-$ & $\checkmark / J$ & active & - & - \\
\hline
\end{tabular}


Continued from previous page

\begin{tabular}{|c|c|c|c|c|c|c|c|c|c|c|c|}
\hline \multirow[b]{2}{*}{ Paper } & & \multirow[b]{2}{*}{$\begin{array}{l}\text { Geogr. } \\
\text { scope }\end{array}$} & \multirow[b]{2}{*}{$\begin{array}{l}\text { Time } \\
\text { horizon }\end{array}$} & \multirow[b]{2}{*}{$\begin{array}{l}\text { RES } \\
\text { shares }\end{array}$} & \multicolumn{2}{|c|}{ Centralized heat } & \multicolumn{3}{|c|}{ Decentralized heat } & \multirow[b]{2}{*}{$\begin{array}{l}\text { Other } \\
\text { sectors }\end{array}$} & \multirow[b]{2}{*}{$\begin{array}{l}\text { Other } \\
\text { features }\end{array}$} \\
\hline & & & & & $\begin{array}{l}\text { Resistive/ } \\
\text { heat } \\
\text { pumps / } \\
\text { CHP }\end{array}$ & $\begin{array}{l}\text { Heat } \\
\text { stor- } \\
\text { age }\end{array}$ & $\begin{array}{l}\text { Resis- } \\
\text { tive/ } \\
\text { hybrid/ } \\
\text { SETS }\end{array}$ & $\begin{array}{l}\text { Heat } \\
\text { pumps / } \\
\text { mCHP }\end{array}$ & $\begin{array}{l}\text { Heat } \\
\text { storage }\end{array}$ & & \\
\hline $\begin{array}{l}\text { Georges et } \\
\text { al. } 2017\end{array}$ & 38 & Belgium & 2016 & $\mathrm{n} / \mathrm{s}$ & $-/-/-$ & - & $(\boldsymbol{J}) /-/-$ & $\checkmark /-$ & $\begin{array}{l}\text { passive, } \\
\text { DHW }\end{array}$ & - & - \\
\hline $\begin{array}{l}\text { Hedegaard et } \\
\text { al. } 2012\end{array}$ & 27] & Denmark & 2020 & $50 \%$ & $(\boldsymbol{J}) /(\boldsymbol{V}) / \mathfrak{J}$ & - & $-/-/-$ & $\checkmark /-$ & $\begin{array}{l}\text { active, } \\
\text { passive }\end{array}$ & $\begin{array}{l}\text { (vehi- } \\
\text { cles) }\end{array}$ & - \\
\hline $\begin{array}{l}\text { Hedegaard, } \\
\text { Balyk } 2013\end{array}$ & 28 & Denmark & 2030 & $60 \%$ & $\checkmark / J / J$ & $\checkmark$ & $\sqrt{ } /-/-$ & $\checkmark /-$ & $\begin{array}{l}\text { passive, } \\
\text { DHW, } \\
\text { active }\end{array}$ & - & - \\
\hline $\begin{array}{l}\text { Hedegaard, } \\
\text { Münster } 2013\end{array}$ & 29] & Denmark & 2030 & $50-60 \%$ & $\checkmark / J / J$ & $\checkmark$ & $\checkmark /-/-$ & $\checkmark /-$ & $\begin{array}{l}\text { passive, } \\
\text { (DHW), } \\
\text { active }\end{array}$ & - & - \\
\hline $\begin{array}{l}\text { Heinen et } \\
\text { al. } 2016\end{array}$ & 59 & Ireland & 2030 & $\begin{array}{l}6 \mathrm{GW} \\
\text { wind }\end{array}$ & $-/-/-$ & - & $\checkmark /-$ & $\checkmark / J /-$ & $\begin{array}{l}\text { DHW, } \\
\text { active }\end{array}$ & - & - \\
\hline $\begin{array}{l}\text { Henning, } \\
\text { Palzer } 2014\end{array}$ & 5 & Germany & $\mathrm{n} / \mathrm{s}(2050)$ & $\begin{array}{l}\text { up to } \\
100 \%\end{array}$ & $\checkmark /-/ \checkmark$ & $\checkmark$ & $\checkmark /-/-$ & $\checkmark / \mathfrak{J}$ & active & - & - \\
\hline Hughes 2010 & 62 & $\begin{array}{l}\text { Prince } \\
\text { Edward } \\
\text { Island, } \\
\text { Canada }\end{array}$ & $2002-2003$ & $\begin{array}{l}5.15 \mathrm{MW} \\
\text { wind } \\
\text { power }\end{array}$ & $-/-/-$ & - & $\checkmark /-/ \mathfrak{d}$ & $-/-$ & - & - & - \\
\hline $\begin{array}{l}\text { Kirkerud et } \\
\text { al. } 2014\end{array}$ & 65 & $\begin{array}{l}\text { Norway, } \\
\text { Sweden }\end{array}$ & $\begin{array}{l}2010-2012 \\
\text { (scenarios) }\end{array}$ & historical & $\checkmark / \sqrt[J]{-}$ & - & $\checkmark /-/-$ & $\checkmark /-$ & - & - & - \\
\hline $\begin{array}{l}\text { Kiviluoma, } \\
\text { Meibom } 2010\end{array}$ & 64 & Finland & 2035 & $8-29 \%$ & $\checkmark / \mathfrak{J}$ & $\checkmark$ & $-/-/-$ & $-/-$ & - & vehicles & - \\
\hline Li et al. 2016 & 71 & $\begin{array}{l}\text { Stylized } \\
\text { urban }\end{array}$ & $\mathrm{n} / \mathrm{s}$ & $\mathrm{n} / \mathrm{s}$ & $-/ \mathfrak{J} / \mathfrak{J}$ & $\checkmark$ & $-/-/-$ & $-/-$ & - & - & - \\
\hline $\begin{array}{l}\text { Liu et } \\
\text { al. } 2016\end{array}$ & 66] & $\begin{array}{l}\text { Beijing, } \\
\text { Tianjin, } \\
\text { Hebei }\end{array}$ & 2015 & $\mathrm{n} / \mathrm{s}$ & $\checkmark /-/ \mathfrak{J}$ & - & $-/-/-$ & $-/-$ & - & - & - \\
\hline $\begin{array}{l}\text { Lund et al. } \\
2010\end{array}$ & 74] & Denmark & $\begin{array}{l}2020,2040, \\
2060\end{array}$ & $\begin{array}{l}\text { Up to } \\
100 \%\end{array}$ & $\checkmark / \mathfrak{J}$ & - & $\sqrt{ } / \mathfrak{J} /-$ & $\checkmark / \checkmark$ & - & $\begin{array}{l}\text { cooling, } \\
\text { ind. heat, } \\
\text { transp., } \mathrm{H}_{2}\end{array}$ & - \\
\hline
\end{tabular}


Continued from previous page

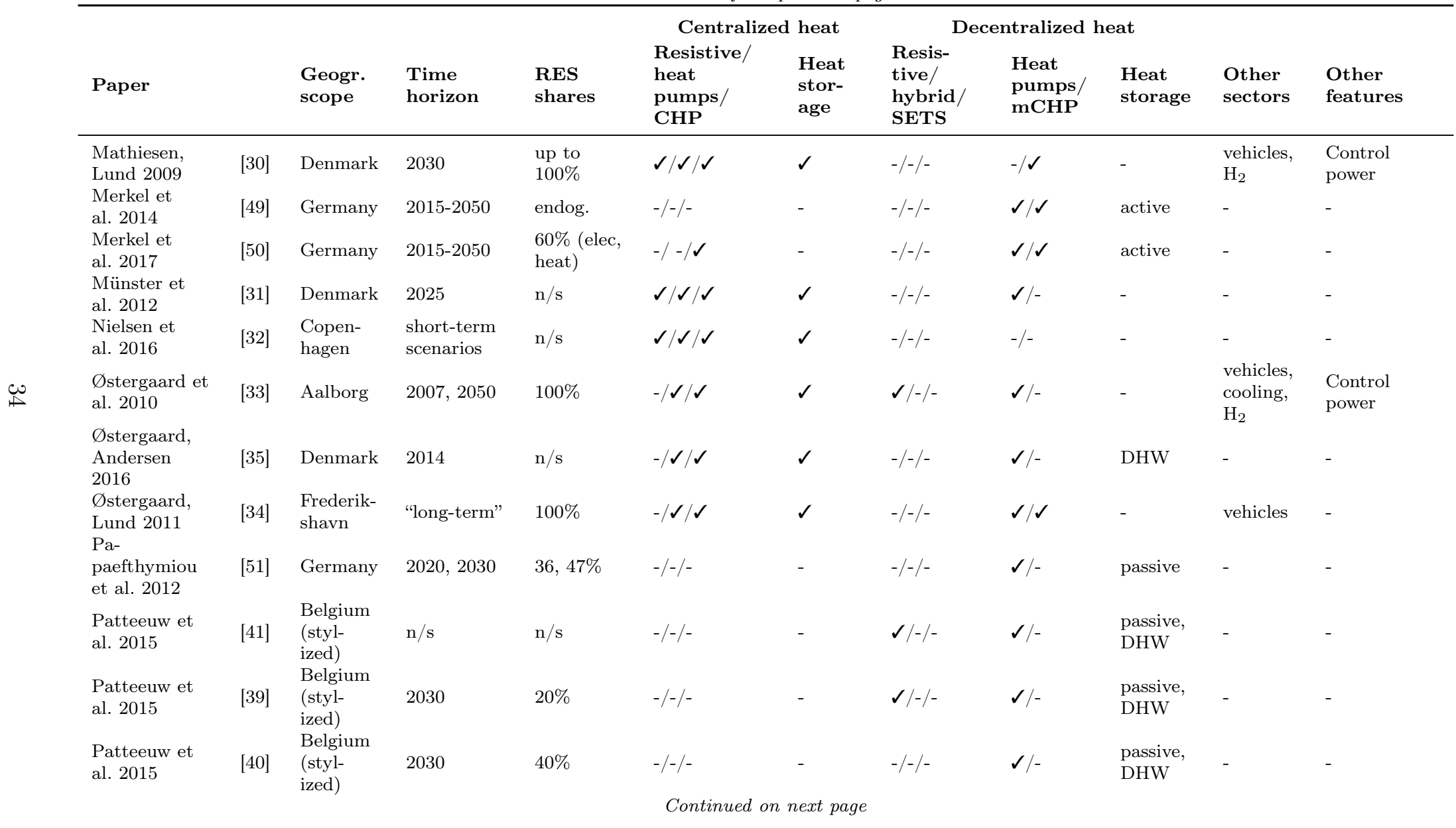


Continued from previous page

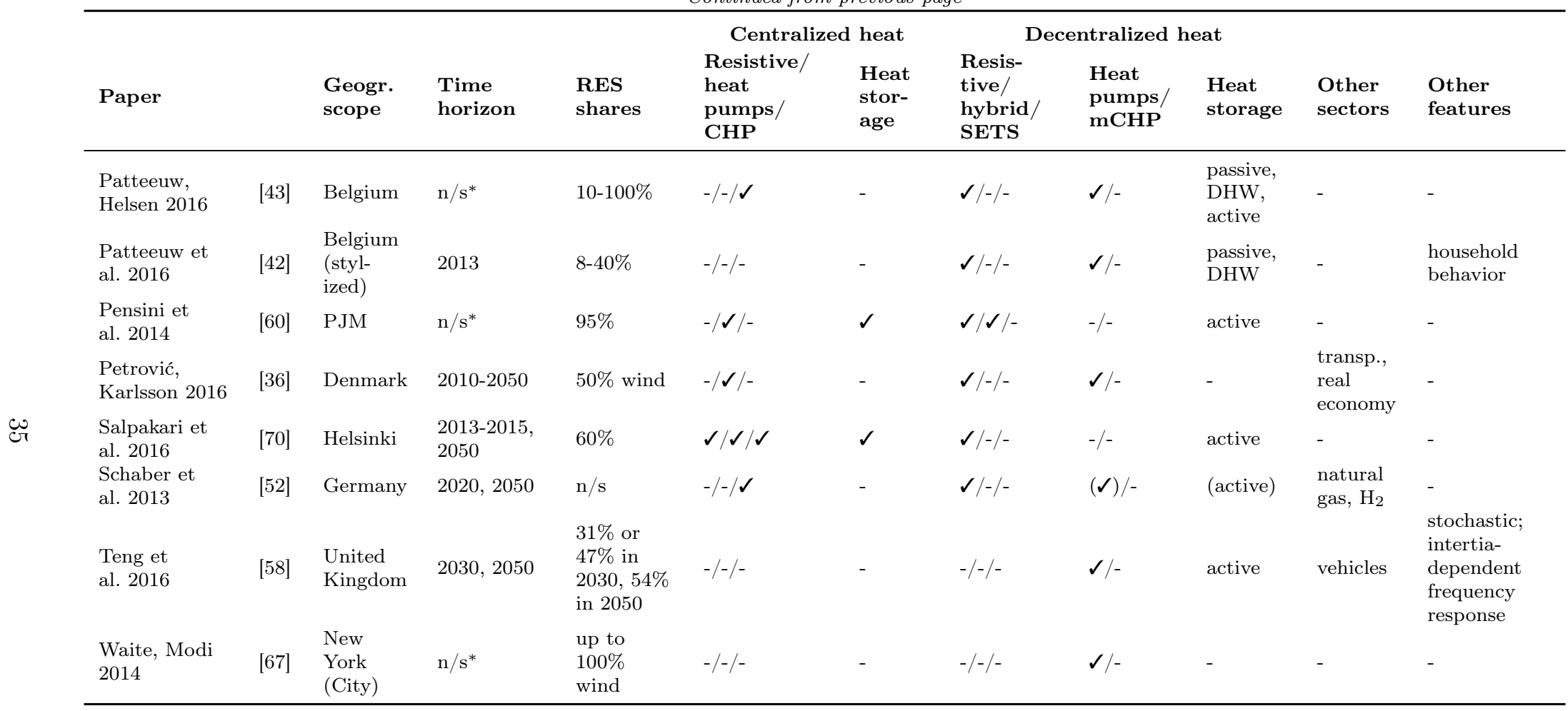

* 43] draw on input data of 2013-2016; 60] 1999-2002; 67] 2005.

Source: Own compilation. Notes: Check marks indicate central consideration of the technology, parentheses a secondary consideration. Abbreviations: DHW: domestic hot water; endog.: endogenous; mCHP: micro combined heat and power; $\mathrm{n} / \mathrm{s}$ : not specified; transp.: transportation 
Table 2: Research method

\begin{tabular}{|c|c|c|c|c|c|c|c|c|}
\hline \multirow{2}{*}{\multicolumn{2}{|c|}{ Paper }} & \multirow{3}{*}{$\begin{array}{l}\text { General method } \\
\text { cost minimization }\end{array}$} & \multirow[b]{2}{*}{$\begin{array}{l}\text { Type of } \\
\text { program }\end{array}$} & \multirow[b]{2}{*}{ Model name } & \multirow[b]{2}{*}{$\begin{array}{l}\text { Time } \\
\text { resolution }\end{array}$} & \multirow[b]{2}{*}{$\begin{array}{l}\text { Endog. in- } \\
\text { vestments }\end{array}$} & \multicolumn{2}{|c|}{ Explicit formulations } \\
\hline & & & & & & & $\mathbf{P} 2 \mathrm{H}$ & $\begin{array}{l}\text { Heat } \\
\text { stor- } \\
\text { age }\end{array}$ \\
\hline Arteconi et al. 2016 & 37 & & MILP & - & hourly, one year & - & $(\sqrt{ })$ & $(\boldsymbol{\checkmark})$ \\
\hline Bach et al. 2016 & 25 & cost minimization & LP & BALMOREL & hourly, 12 weeks & - & - & - \\
\hline Barton et al. 2013 & 55 & scenario assessment & $\mathrm{n} / \mathrm{a}$ & FESA & hourly, one year & - & - & - \\
\hline Bauermann et al. 2014 & 44] & cost minimization & stochastic LPs & E2M2, HeatSyM & $\begin{array}{l}\text { Time steps } \\
\text { (days, hours) }\end{array}$ & power, heat & - & - \\
\hline Blarke 2012 & 26] & cost minimization & MILP & COMPOSE & hourly, one year & - & - & - \\
\hline Böttger et al. 2014 & 45 & analysis of potentials & $\mathrm{n} / \mathrm{a}$ & - & hourly, one year & - & - & - \\
\hline Böttger et al. 2015 & 46 & cost minimization & MILP & MICOES-Europe & hourly, one year & - & $\checkmark$ & $\checkmark$ \\
\hline Chen et al. 2014 & 61 & $\begin{array}{l}\text { minimization of } \\
\text { residual demand } \\
\text { variability }\end{array}$ & $\mathrm{QP}$ & - & hourly, one year & - & $\checkmark$ & $\checkmark$ \\
\hline Connolly et al. 2016 & 63 & simulation & $\mathrm{n} / \mathrm{s}$ & EnergyPLAN & hourly, one year & - & - & - \\
\hline Cooper et al. 2016 & 56] & building simulation & $\mathrm{n} / \mathrm{s}$ & - & $\begin{array}{l}\text { one minute, (90 } \\
\text { days) }\end{array}$ & - & - & - \\
\hline Dodds 2014 & 57] & cost minimization & LP & UK MARKAL & 72 time slices & $\begin{array}{l}\text { (power), } \\
\text { heat }\end{array}$ & - & - \\
\hline Ehrlich et al. 2015 & 47 & cost minimization & LP & - & hourly, one year & - & $\checkmark$ & $\checkmark$ \\
\hline Fehrenbach et al. 2014 & 48 & cost minimization & LP & TIMES & Time slices & power, heat & - & - \\
\hline Georges et al. 2014 & 38 & $\begin{array}{l}\text { flexibility } \\
\text { maximization }\end{array}$ & MILP & - & $\begin{array}{l}15 \text { minutes, } 3.5 \\
\text { days }\end{array}$ & - & $\checkmark$ & $\checkmark$ \\
\hline
\end{tabular}


Continued from previous page

\begin{tabular}{|c|c|c|c|c|c|c|c|c|}
\hline \multirow{2}{*}{\multicolumn{2}{|c|}{ Paper }} & \multirow[b]{2}{*}{ General method } & \multirow[b]{2}{*}{$\begin{array}{l}\text { Type of } \\
\text { program }\end{array}$} & \multirow[b]{2}{*}{ Model name } & \multirow[b]{2}{*}{$\begin{array}{l}\text { Time } \\
\text { resolution }\end{array}$} & \multirow[b]{2}{*}{$\begin{array}{l}\text { Endog. in- } \\
\text { vestments }\end{array}$} & \multicolumn{2}{|c|}{ Explicit formulations } \\
\hline & & & & & & & $\mathbf{P 2 H}$ & $\begin{array}{l}\text { Heat } \\
\text { stor- } \\
\text { age }\end{array}$ \\
\hline Hedegaard et al. 2012 & 27 & simulation & $\mathrm{n} / \mathrm{s}$ & EnergyPLAN & hourly, one year & - & $\checkmark$ & $\checkmark$ \\
\hline $\begin{array}{l}\text { Hedegaard, Balyk } \\
2013\end{array}$ & 28 & cost minimization & LP & $\begin{array}{l}\text { BALMOREL, } \\
\text { building add-on }\end{array}$ & hourly, 4 weeks & power, heat & $\checkmark$ & $\checkmark$ \\
\hline $\begin{array}{l}\text { Hedegaard, Münster } \\
2013\end{array}$ & 29] & cost minimization & LP & $\begin{array}{l}\text { BALMOREL, } \\
\text { building add-on }\end{array}$ & hourly, 5 weeks & power, heat & - & - \\
\hline Heinen et al. 2016 & 59] & cost minimization & LP & - & hourly & power, heat & $\checkmark$ & $\checkmark$ \\
\hline Henning, Palzer 2014 & $\frac{54,}{53}$ & $\begin{array}{l}\text { iterative heuristic } \\
\text { calibration }\end{array}$ & $\mathrm{n} / \mathrm{a}$ & REMod-D & hourly, one year & - & $\checkmark$ & $\checkmark$ \\
\hline Hughes 2010 & 62 & $\begin{array}{l}\text { data analyses, } \\
\text { heuristic simulation }\end{array}$ & $\mathrm{n} / \mathrm{a}$ & - & hourly, one year & - & - & - \\
\hline Kirkerud et al. 2014 & 65] & cost minimization & LP & BALMOREL & $\begin{array}{l}1,768 \text { time slices, } \\
52 \text { weeks }\end{array}$ & - & - & - \\
\hline $\begin{array}{l}\text { Kiviluoma, Meibom } \\
2010\end{array}$ & 64 & cost minimization & LP & BALMOREL & hourly, 26 weeks & power, heat & - & - \\
\hline Li et al. 2016 & 71 & cost minimization & NLP & - & hourly, one year & - & $\checkmark$ & $\checkmark$ \\
\hline Liu et al. 2016 & 66] & $\begin{array}{l}\text { welfare } \\
\text { maximization }\end{array}$ & LP & - & $\begin{array}{l}15 \text { minutes, } \\
2,880 \text { hours }\end{array}$ & - & - & - \\
\hline Lund et al. 2010 & 74 & simulation & $\mathrm{n} / \mathrm{s}$ & EnergyPLAN & hourly, one year & - & - & - \\
\hline Mathiesen, Lund 2009 & 30 & simulation & $\mathrm{n} / \mathrm{s}$ & EnergyPLAN & hourly, one year & - & - & - \\
\hline Merkel et al. 2014 & 49] & cost minimization & MILP & $\begin{array}{l}\text { TIMES, } \\
\text { customized }\end{array}$ & hourly, 48 hours & heat & - & $\checkmark$ \\
\hline Merkel et al. 2017 & 50] & cost minimization & MILP & $\begin{array}{l}\text { TIMES-HEAT- } \\
\text { POWER }\end{array}$ & $\begin{array}{l}6,048 \text { hours } \\
\text { (heat), } 48 \text { time } \\
\text { slices (system) }\end{array}$ & power, heat & - & - \\
\hline
\end{tabular}


Continued from previous page

\begin{tabular}{|c|c|c|c|c|c|c|c|c|}
\hline \multirow[b]{2}{*}{ Paper } & & \multirow[b]{2}{*}{ General method } & \multirow[b]{2}{*}{$\begin{array}{l}\text { Type of } \\
\text { program }\end{array}$} & \multirow[b]{2}{*}{ Model name } & \multirow[b]{2}{*}{$\begin{array}{l}\text { Time } \\
\text { resolution }\end{array}$} & \multirow[b]{2}{*}{$\begin{array}{l}\text { Endog. in- } \\
\text { vestments }\end{array}$} & \multicolumn{2}{|c|}{ Explicit formulations } \\
\hline & & & & & & & $\mathbf{P 2 H}$ & $\begin{array}{l}\text { Heat } \\
\text { stor- } \\
\text { age }\end{array}$ \\
\hline Münster et al. 2012 & 31 & cost minimization & LP & BALMOREL & $\mathrm{n} / \mathrm{a}$ & power, heat & - & - \\
\hline Nielsen et al. 2016 & 32 & cost minimization & MILP & - & hourly, 24 hours & - & $\checkmark$ & $\checkmark$ \\
\hline Østergaard et al. 2010 & 33 & simulation & $\mathrm{n} / \mathrm{s}$ & EnergyPLAN & hourly & - & - & - \\
\hline $\begin{array}{l}\text { Østergaard, Andersen } \\
2016\end{array}$ & 35 & dispatch simulation & $\mathrm{n} / \mathrm{a}$ & energyPRO & hourly, one year & $\mathrm{n} / \mathrm{s}$ & $(\checkmark)$ & $(\checkmark)$ \\
\hline Østergaard, Lund 2011 & 34 & simulation & $\mathrm{n} / \mathrm{s}$ & EnergyPLAN & hourly, one year & - & - & - \\
\hline $\begin{array}{l}\text { Papaefthymiou et } \\
\text { al. } 2012\end{array}$ & 51 & cost minimization & Stochastic MILP & PowerFys & hourly, one year & - & $\checkmark$ & $\checkmark$ \\
\hline Patteeuw et al. 2015 & 41] & cost minimization & MILP & - & hourly, 48 hours & - & $\checkmark$ & $\checkmark$ \\
\hline Patteeuw et al. 2015 & 39 & cost minimization & MILP & - & hourly, 48 hours & - & $\checkmark$ & $\checkmark$ \\
\hline Patteeuw et al. 2015 & 40 & cost minimization & MILP & - & hourly, one year & $\begin{array}{l}\text { (power, } \\
\text { heat) }\end{array}$ & - & - \\
\hline Patteeuw, Helsen 2016 & 43] & cost minimization & MILP & - & hourly, one week & $\begin{array}{l}\text { (power, } \\
\text { heat) }\end{array}$ & $\checkmark$ & $\checkmark$ \\
\hline Patteeuw et al. 2016 & 42 & cost minimization & MILP & - & hourly, one year & - & $\checkmark$ & $\checkmark$ \\
\hline Pensini et al. 2014 & 60 & $\begin{array}{l}\text { (heuristic) cost } \\
\text { minimization }\end{array}$ & $\mathrm{n} / \mathrm{a}$ & - & hourly, 4 years & heat & - & - \\
\hline $\begin{array}{l}\text { Petrović, Karlsson } \\
2016\end{array}$ & 36 & cost minimization & LP & TIMES-DK & time slices & power, heat & - & - \\
\hline Salpakari et al. 2016 & 70 & $\begin{array}{l}\text { minimization of } \\
\text { residual load }\end{array}$ & MILP & - & hourly, 24 hours & - & $\checkmark$ & $\checkmark$ \\
\hline Schaber et al. 2013 & 52 & cost minimization & LP & URBS-D & hourly, 6 weeks & power, heat & - & - \\
\hline & & & Contin & $d$ on next page & & & & \\
\hline
\end{tabular}


Continued from previous page

\begin{tabular}{|c|c|c|c|c|c|c|c|c|}
\hline \multirow[b]{2}{*}{ Paper } & & \multirow[b]{2}{*}{ General method } & \multirow[b]{2}{*}{$\begin{array}{l}\text { Type of } \\
\text { program }\end{array}$} & \multirow[b]{2}{*}{ Model name } & \multirow[b]{2}{*}{$\begin{array}{l}\text { Time } \\
\text { resolution }\end{array}$} & \multirow[b]{2}{*}{$\begin{array}{l}\text { Endog. in- } \\
\text { vestments }\end{array}$} & \multicolumn{2}{|c|}{ Explicit formulations } \\
\hline & & & & & & & $\mathbf{P} 2 \mathrm{H}$ & $\begin{array}{l}\text { Heat } \\
\text { stor- } \\
\text { age }\end{array}$ \\
\hline Teng et al. 2016 & 58 & cost minimization & MILP & ASUC & hourly, one year & - & - & - \\
\hline Waite, Modi 2014 & 67] & dispatch simulation & $\mathrm{LP}, \mathrm{n} / \mathrm{a}$ & - & hourly, one year & $\begin{array}{l}\text { (pre- } \\
\text { optimization) }\end{array}$ & $\checkmark$ & - \\
\hline
\end{tabular}

Source: Own compilation. Notes: Parentheses indicate a secondary consideration. Abbreviations: LP: linear program; MILP: mixed integer linear program; NLP: non-linear program; n/a: not applicable; n/s: not specified; QP: quadratic program 
Table 3: Research focus and questions

\begin{tabular}{|c|c|c|c|c|c|c|c|c|}
\hline Paper & & $\begin{array}{l}\text { Cost effec- } \\
\text { tiveness }\end{array}$ & $\begin{array}{l}\text { RES } \\
\text { integration }\end{array}$ & $\begin{array}{l}\text { Decar- } \\
\text { bonization }\end{array}$ & $\begin{array}{l}\text { Power } \\
\text { prices }\end{array}$ & $\begin{array}{l}\text { Electricity } \\
\text { demand for } \\
\text { P2H }\end{array}$ & $\begin{array}{l}\text { Structure } \\
\text { of heat } \\
\text { supply }\end{array}$ & $\begin{array}{l}\text { Method- } \\
\text { ological } \\
\text { contribu- } \\
\text { tion }\end{array}$ \\
\hline Arteconi et al. 2016 & 37 & $\checkmark$ & $\checkmark$ & - & $\checkmark$ & - & - & - \\
\hline Bach et al. 2016 & 25 & $(\checkmark)$ & $(\sqrt{ })$ & - & $(\sqrt{ })$ & - & $\checkmark$ & $(\sqrt{ })$ \\
\hline Barton et al. 2013 & 55 & - & $(\sqrt{ })$ & $\checkmark$ & - & $\checkmark$ & - & - \\
\hline Bauermann et al. 2014 & 44] & - & - & - & $\checkmark$ & - & $\checkmark$ & $\checkmark$ \\
\hline Blarke 2012 & 26 & $(\boldsymbol{})$ & $(\boldsymbol{})$ & $(\boldsymbol{J})$ & - & - & - & - \\
\hline Böttger et al. 2014 & 45 & - & $\checkmark$ & - & - & $(\boldsymbol{\checkmark})$ & - & - \\
\hline Böttger et al. 2015 & 46 & $\checkmark$ & $(\sqrt{ })$ & $\checkmark$ & $(\sqrt{ })$ & - & - & $\checkmark$ \\
\hline Chen et al. 2014 & 61 & $\checkmark$ & 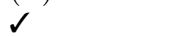 & $\checkmark$ & - & $(\boldsymbol{\checkmark})$ & - & - \\
\hline Connolly et al. 2016 & 63 & $(\checkmark)$ & $\checkmark$ & $\checkmark$ & - & $\checkmark$ & $(\checkmark)$ & - \\
\hline Cooper et al. 2016 & 56 & - & - & - & - & $\checkmark$ & $(\checkmark)$ & - \\
\hline Dodds 2014 & 57 & $(\boldsymbol{\checkmark})$ & - & $(\boldsymbol{\checkmark})$ & - & - & $\checkmark$ & $\checkmark$ \\
\hline Ehrlich et al. 2015 & 47] & - & $(\checkmark)$ & - & $(\checkmark)$ & - & - & $\checkmark$ \\
\hline Fehrenbach et al. 2014 & 48 & $(\boldsymbol{\checkmark})$ & $(\mathcal{l})$ & $(\boldsymbol{\checkmark})$ & - & - & $\checkmark$ & $(\sqrt{ })$ \\
\hline Georges et al. 2014 & 38 & - & - & - & - & - & - & 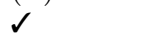 \\
\hline Hedegaard et al. 2012 & 27 & $(\sqrt{ })$ & $\checkmark$ & $(\boldsymbol{\checkmark})$ & - & - & - & $(\sqrt{ })$ \\
\hline Hedegaard, Balyk 2013 & 28 & $(\checkmark)$ & $(\sqrt{ })$ & - & $(\boldsymbol{J})$ & - & - & $\checkmark$ \\
\hline Hedegaard, Münster 2013 & 29 & 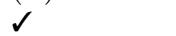 & $\checkmark$ & $(\checkmark)$ & - & - & - & - \\
\hline Heinen et al. 2016 & 59 & $\checkmark$ & $(\checkmark)$ & $(\checkmark)$ & - & - & $\checkmark$ & $\checkmark$ \\
\hline Henning, Palzer 2014 & 54. 53] & $\checkmark$ & $\checkmark$ & $(\sqrt{ })$ & - & - & - & $\checkmark$ \\
\hline Hughes 2010 & 62 & - & 2 & $(\checkmark)$ & - & - & - & - \\
\hline Kirkerud et al. 2014 & 65 & - & - & - & $\checkmark$ & $\checkmark$ & - & - \\
\hline Kiviluoma, Meibom 2010 & 64 & $\checkmark$ & $\checkmark$ & $\checkmark$ & - & - & $\checkmark$ & - \\
\hline $\mathrm{Li}$ et al. 2016 & 711 & $\checkmark$ & $(\checkmark)$ & - & - & - & - & $\checkmark$ \\
\hline Liu et al. 2016 & 66 & $\checkmark$ & $\checkmark$ & $(\boldsymbol{J})$ & - & - & - & $\checkmark$ \\
\hline Lund et al. 2010 & 74 & $(\sqrt{ })$ & $\checkmark$ & $\checkmark$ & - & - & - & - \\
\hline Mathiesen, Lund 2009 & 30 & $\checkmark$ & $\checkmark$ & $(\sqrt{ })$ & - & - & $(\sqrt{ })$ & \\
\hline Merkel et al. 2014 & 49 & $(\sqrt{ })$ & - & - & - & - & 2 & $\checkmark$ \\
\hline Merkel et al. 2017 & 50 & $(\checkmark)$ & - & $\checkmark$ & - & $\checkmark$ & $\checkmark$ & - \\
\hline Münster et al. 2012 & 31 & $(\checkmark)$ & $(\sqrt{ })$ & - & - & - & $\checkmark$ & $\checkmark$ \\
\hline
\end{tabular}


Continued from previous page

\begin{tabular}{|c|c|c|c|c|c|c|c|c|}
\hline Paper & & $\begin{array}{l}\text { Cost effec- } \\
\text { tiveness }\end{array}$ & $\begin{array}{l}\text { RES } \\
\text { integration }\end{array}$ & $\begin{array}{l}\text { Decar- } \\
\text { bonization }\end{array}$ & $\begin{array}{l}\text { Power } \\
\text { prices }\end{array}$ & $\begin{array}{l}\text { Electricity } \\
\text { demand for } \\
\text { P2H }\end{array}$ & $\begin{array}{l}\text { Structure } \\
\text { of heat } \\
\text { supply }\end{array}$ & $\begin{array}{l}\text { Method- } \\
\text { ological } \\
\text { contribu- } \\
\text { tion }\end{array}$ \\
\hline Nielsen et al. 2016 & 35 & - & - & - & $(\boldsymbol{J})$ & - & $(\boldsymbol{\checkmark})$ & $\checkmark$ \\
\hline Østergaard et al. 2010 & 33 & $(\checkmark)$ & $\checkmark$ & $\checkmark$ & - & - & $(\checkmark)$ & - \\
\hline Østergaard, Andersen 2016 & 35 & 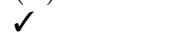 & - & - & - & $(\boldsymbol{J})$ & $(\boldsymbol{J})$ & $(\boldsymbol{\checkmark})$ \\
\hline Østergaard, Lund 2011 & 34 & $(\boldsymbol{\checkmark})$ & $\checkmark$ & $(\boldsymbol{\checkmark})$ & - & - & $\checkmark$ & - \\
\hline Papaefthymiou et al. 2012 & 51 & $\checkmark$ & $(\boldsymbol{\checkmark})$ & $\checkmark$ & - & - & - & $\checkmark$ \\
\hline Patteeuw et al. 2015 & 41] & - & - & - & - & - & & $\checkmark$ \\
\hline Patteeuw et al. 2015 & 39 & $(\boldsymbol{\checkmark})$ & - & - & $(\boldsymbol{J})$ & $\checkmark$ & - & $\checkmark$ \\
\hline Patteeuw et al. 2015 & 40 & $\checkmark$ & $\checkmark$ & $\checkmark$ & - & $\checkmark$ & - & - \\
\hline Patteeuw, Helsen 2016 & 43 & $\checkmark$ & $(\checkmark)$ & $\checkmark$ & - & - & $\checkmark$ & $\checkmark$ \\
\hline Patteeuw et al. 2016 & 42 & $\checkmark$ & $\checkmark$ & $(\boldsymbol{J})$ & $(\boldsymbol{\checkmark})$ & - & - & $\checkmark$ \\
\hline Pensini et al. 2014 & 60 & $\checkmark$ & $\checkmark$ & $(\boldsymbol{J})$ & - & - & $\checkmark$ & - \\
\hline Petrović, Karlsson 2016 & 36 & $\checkmark$ & $(\boldsymbol{\checkmark})$ & $(\boldsymbol{\checkmark})$ & - & - & $\checkmark$ & $(\boldsymbol{\checkmark})$ \\
\hline Salpakari et al. 2016 & 70 & - & $\checkmark$ & - & - & - & - & $\checkmark$ \\
\hline Schaber et al. 2013 & 52 & $\checkmark$ & $\checkmark$ & $(\checkmark)$ & - & $\checkmark$ & - & - \\
\hline Teng et al. 2016 & 58 & $\checkmark$ & 2 & s & - & - & - & - \\
\hline Waite, Modi 2014 & 67 & $(\boldsymbol{\checkmark})$ & $\checkmark$ & $(\boldsymbol{\checkmark})$ & - & $(\boldsymbol{\checkmark})$ & - & $(\boldsymbol{J})$ \\
\hline
\end{tabular}

Source: Own compilation. Note: Parentheses indicate a secondary consideration. 


\section{References}

[1] UNO, Paris Agreement 2015.

URL http://unfccc.int/files/essential_background/ convention/application/pdf/english_paris_agreement.pdf

[2] P. A. Østergaard, Comparing electricity, heat and biogas storages' impacts on renewable energy integration, Energy 37 (1) (2012) 255-262. doi:10.1016/j.energy.2011.11.039

[3] O. Lucon, D. Ürge-Vorsatz, A. Zain Ahmed, H. Akbari, P. Bertoldi, L. F. Cabeza, N. Eyre, A. Gadgil, L. D. Harvey, Y. Jiang, E. Liphoto, S. Mirasgedis, S. Murakami, J. Parikh, C. Pyke, M. V. Vilariño, Buildings, in: Climate Change 2014: Mitigation of Climate Change. Contribution of Working Group III to the Fifth Assessment Report of the Intergovernmental Panel on Climate Change, Cambridge University Press, 2014.

[4] J.-F. Hake, W. Fischer, S. Venghaus, C. Weckenbrock, The German Energiewende - History and status quo, Energy 92, Part 3 (2015) 532546. doi:10.1016/j.energy.2015.04.027.

[5] K. Bauermann, German energiewende and the heating market - impact and limits of policy, Energy Policy 94 (2016) 235 - 246. doi:10.1016/ j.enpol.2016.03.041.

[6] I. J. Perez-Arriaga, C. Batlle, Impacts of intermittent renewables on electricity generation system operation, Economics of Energy \& Environmental Policy 1 (2) (2012) 3-17. doi:10.5547/2160-5890.1.2.1.

[7] D. Lew, G. Brinkman, E. Ibanez, A. Florita, M. Heaney, B.-M. Hodge, M. Hummon, G. Stark, J. King, S. Lefton, et al., The Western Wind and Solar Integration Study Phase 2, Tech. rep., National Renewable Energy Lab.(NREL), Golden, CO (United States) (2013).

[8] W.-P. Schill, M. Pahle, C. Gambardella, Start-up costs of thermal power plants in markets with increasing shares of variable renewable genera- 
tion, Nature Energy 2, Article number: 17050. doi:10.1038/nenergy. 2017.50 .

[9] A. Zerrahn, W.-P. Schill, Long-run power storage requirements for high shares of renewables: review and a new model, Renewable and Sustainable Energy Reviewsdoi:10.1016/j.rser.2016.11.098.

[10] H. Kondziella, T. Bruckner, Flexibility requirements of renewable energy based electricity systems - a review of research results and methodologies, Renewable and Sustainable Energy Reviews 53 (2016) 10 - 22. doi:https://doi.org/10.1016/j.rser.2015.07.199.

[11] S. Stinner, K. Huchtemann, D. Müller, Quantifying the operational flexibility of building energy systems with thermal energy storages, Applied Energy 181 (2016) 140-154. doi:10.1016/j.apenergy.2016.08.055.

[12] D. B. Richardson, Electric vehicles and the electric grid: A review of modeling approaches, impacts, and renewable energy integration, Renewable and Sustainable Energy Reviews 19 (2013) 247 - 254. doi: $10.1016 / j$.rser.2012.11.042.

[13] J. Barton, R. Gammon, The production of hydrogen fuel from renewable sources and its role in grid operations, Journal of Power Sources 195 (24) (2010) 8222-8235. doi:10.1016/j · jpowsour.2009.12.100

[14] S. Schiebahn, T. Grube, M. Robinius, V. Tietze, B. Kumar, D. Stolten, Power to gas: Technological overview, systems analysis and economic assessment for a case study in Germany , International Journal of Hydrogen Energy 40 (12) (2015) 4285 - 4294. doi:10.1016/j.ijhydene. 2015.01.123.

[15] M. Götz, J. Lefebvre, F. Mörs, A. McDaniel Koch, F. Graf, S. Bajohr, R. Reimert, T. Kolb, Renewable power-to-gas: A technological and economic review, Renewable Energy 85 (2016) 1371 - 1390. doi:10.1016/j.renene.2015.07.066. 
[16] D. Olsthoorn, F. Haghighat, P. A. Mirzaei, Integration of storage and renewable energy into district heating systems: A review of modelling and optimization, Solar Energy 136 (2016) 49-64. doi:10.1016/j. solener.2016.06.054.

[17] H. Lund, S. Werner, R. Wiltshire, S. Svendsen, J. E. Thorsen, F. Hvelplund, B. V. Mathiesen, 4th Generation District Heating (4gdh), Energy 68 (2014) 1-11. doi:10.1016/j.energy.2014.02.089, URL http://www.sciencedirect.com/science/article/pii/ S0360544214002369

[18] Z. Li, W. Wu, M. Shahidehpour, J. Wang, B. Zhang, Combined Heat and Power Dispatch Considering Pipeline Energy Storage of District Heating Network, IEEE Transactions on Sustainable Energy 7 (1) (2016) 12-22. doi:10.1109/TSTE. 2015.2467383.

[19] G. Reynders, T. Nuytten, D. Saelens, Potential of structural thermal mass for demand-side management in dwellings, Building and Environment 64 (2013) 187 - 199. doi:10.1016/j.buildenv.2013.03.010.

[20] J. Kensby, A. Trüschel, J.-O. Dalenbäck, Potential of residential buildings as thermal energy storage in district heating systems âĂŞ Results from a pilot test, Applied Energy 137 (2015) 773-781. doi: $10.1016 / j$.apenergy.2014.07.026

[21] J. Le Dréau, P. Heiselberg, Energy flexibility of residential buildings using short term heat storage in the thermal mass, Energy 111 (2016) 991-1002. doi:10.1016/j.energy.2016.05.076

[22] K. Chua, S. Chou, W. Yang, Advances in heat pump systems: A review, Applied Energy 87 (12) (2010) 3611 - 3624. doi:10.1016/j . apenergy . 2010.06 .014

[23] D. Fischer, H. Madani, On heat pumps in smart grids: A review, Renewable and Sustainable Energy Reviews 70 (2017) 342 - 357. doi: $10.1016 /$ j.rser.2016.11.182. 
[24] W. Schulz, Wärmenetze für die Energiewende, Energie \& Management (2011) 17.

[25] B. Bach, J. Werlin, T. Ommen, M. Münster, J. M. Morales, B. Elmegaards, Integration of large-scale heat pumps in the district heating system of Greater Copenhagen, Energy 107 (2016) 321-334. doi:10.1016/j.energy.2016.04.029.

[26] M. Blarke, Towards an intermittency-friendly energy system: Comparing electric boilers and heat pumps in distributed cogeneration, Applied Energy 91 (1) (2012) 349-365. doi:10.1016/j.apenergy. 2011. 09.038 .

[27] K. Hedegaard, B. Mathiesen, H. Lund, P. Heiselberg, Wind power integration using individual heat pumps - Analysis of different heat storage options, Energy 47 (1) (2012) 284-293. doi:10.1016/j.energy.2012. 09.030 .

[28] K. Hedegaard, O. Balyk, Energy system investment model incorporating heat pumps with thermal storage in buildings and buffer tanks, Energy 63 (2013) 356-365. doi:10.1016/j .energy.2013.09.061.

[29] K. Hedegaard, M. Münster, Influence of individual heat pumps on wind power integration - Energy system investments and operation, Energy Conversion and Management 75 (2013) 673-684. doi:10.1016/ j.enconman.2013.08.015.

[30] B. V. Mathiesen, H. Lund, Comparative analyses of seven technologies to facilitate the integration of fluctuating renewable energy sources, IET Renewable Power Generation 3 (2) (2009) 190-204. doi:10.1049/ iet-rpg:20080049.

[31] M. Münster, P. E. Morthorst, H. V. Larsen, L. Bregnbæk, J. Werling, H. H. Lindboe, H. Ravn, The role of district heating in the future Danish energy system, Energy 48 (2012) 47-55. doi:10.1016/j.energy. 2012. 06.011 . 
[32] M. G. Nielsen, J. M. Morales, M. Zugno, T. E. Pedersen, H. Madsen, Economic valuation of heat pumps and electric boilers in the Danish energy system, Applied Energy 167 (2016) 189-200. doi:10.1016/j. apenergy.2015.08.115.

[33] P. A. Østergaard, B. V. Mathiesen, B. Möller, H. Lund, A renewable energy scenario for Aalborg Municipality based on low-temperature geothermal heat, wind power and biomass, Energy 35 (12) (2010) 4892 4901. doi:10.1016/j.energy.2010.08.041.

[34] P. A. Østergaard, H. Lund, A renewable energy system in Frederikshavn using low-temperature geothermal energy for district heating, Applied Energy 88 (2) (2011) 479-487. doi:10.1016/j.apenergy.2010. 03.018.

[35] P. A. Østergaard, A. N. Andersen, Booster heat pumps and central heat pumps in district heating, Applied Energy 184 (2016) 1374-1388. doi:10.1016/j.apenergy.2016.02.144.

[36] S. N. Petrović, K. B. Karlsson, Residential heat pumps in the future Danish energy system, Energy 114 (2016) 787-797. doi:10.1016/j. energy.2016.08.007.

[37] A. Arteconi, D. Patteeuw, K. Bruninx, E. Delarue, W. D'haeseleer, L. Helsen, Active demand response with electric heating systems: Impact of market penetration, Applied Energy 177 (2016) 636-648. doi: $10.1016 / \mathrm{j}$. apenergy .2016.05.146.

[38] E. Georges, B. Cornélusse, D. Ernst, V. Lemort, S. Mathieu, Residential heat pump as flexible load for direct control service with parametrized duration and rebound effect, Applied Energy 187 (2017) 140-153. doi: $10.1016 / \mathrm{j}$. apenergy.2016.11.012.

[39] D. Patteeuw, K. Bruninx, A. Arteconi, E. Delarue, W. D'haeseleer, L. Helsen, Integrated modeling of active demand response with electric heating systems coupled to thermal energy storage systems, Applied Energy 151 (2015) 306-319. doi:10.1016/j.apenergy.2015.04.014. 
[40] D. Patteeuw, G. Reynders, K. Bruninx, C. Protopapadaki, E. Delarue, W. D'haeseleer, D. Saelens, L. Helsen, CO2-abatement cost of residential heat pumps with active demand response: demand-and supply-side effects, Applied Energy 156 (2015) 490-501. doi:10.1016/j . apenergy . 2015.07.038.

[41] D. Patteeuw, K. Bruninx, E. Delarue, L. Helsen, W. D'haeseleer, Short-term demand response of flexible electric heating systems: an integrated model., TME Working Paper EN2014-28.

URL https://www.mech.kuleuven.be/en/tme/research/energy_ environment/Pdf/wpen2014-28.pdf

[42] D. Patteeuw, G. P. Henze, L. Helsen, Comparison of load shifting incentives for low-energy buildings with heat pumps to attain grid flexibility benefits, Applied Energy 167 (2016) 80-92. doi:10.1016/j .apenergy. 2016.01 .036

[43] D. Patteeuw, L. Helsen, Combined design and control optimization of residential heating systems in a smart-grid context, Energy and Buildings 133 (2016) 640-657. doi:10.1016/j.enbuild.2016.09.030.

[44] K. Bauermann, S. Spiecker, C. Weber, Individual decisions and system development - Integrating modelling approaches for the heating market, Applied Energy 116 (2014) 149-158. doi:10.1016/j.apenergy.2013. 11.046.

[45] D. Böttger, M. Götz, N. Lehr, H. Kondziella, T. Bruckner, Potential of the Power-to-Heat Technology in District Heating Grids in Germany, Energy Procedia 46 (2014) 246-253. doi:10.1016/j.egypro.2014.01. 179 .

[46] D. Böttger, M. Götz, M. Theofilidi, T. Bruckner, Control power provision with power-to-heat plants in systems with high shares of renewable energy sources - An illustrative analysis for Germany based on the use of electric boilers in district heating grids, Energy 82 (2015) 157-167. doi:10.1016/j.energy.2015.01.022. 
[47] L. G. Ehrlich, J. Klamka, A. Wolf, The potential of decentralized power-to-heat as a flexibility option for the german electricity system: A microeconomic perspective, Energy Policy 87 (2015) 417-428. doi:10.1016/j.enpol.2015.09.032.

[48] D. Fehrenbach, E. Merkel, R. McKenna, U. Karl, W. Fichtner, On the economic potential for electric load management in the German residential heating sector - An optimising energy system model approach, Energy 71 (2014) 263-276. doi:10.1016/j.energy.2014.04.061.

[49] E. Merkel, D. Fehrenbach, R. McKenna, W. Fichtner, Modelling decentralised heat supply: An application and methodological extension in TIMES, Energy 73 (2014) 592-605. doi:10.1016/j.energy.2014.06. 060.

[50] E. Merkel, R. McKenna, D. Fehrenbach, W. Fichtner, A model-based assessment of climate and energy targets for the German residential heat system, Journal of Cleaner Production 142 (2017) 3151-3173. doi: $10.1016 / \mathrm{j} \cdot \mathrm{jclepro} .2016 .10 .153$.

[51] G. Papaefthymiou, B. Hasche, C. Nabe, Potential of Heat Pumps for Demand Side Management and Wind Power Integration in the German Electricity Market, IEEE Transactions on Sustainable Energy 3 (4) (2012) 636-642. doi:10.1109/TSTE.2012.2202132.

[52] K. Schaber, F. Steinke, T. Hamacher, Managing Temporary Oversupply from Renewables Efficiently: Electricity Storage Versus Energy Sector Coupling in Germany, International Energy Workshop Paris.

URL http://www.internationalenergyworkshop.org/docs/IEW\% 202013_4E3paperSchaber.pdf

[53] A. Palzer, H.-M. Henning, A comprehensive model for the German electricity and heat sector in a future energy system with a dominant contribution from renewable energy technologies - Part II: Results, Renewable and Sustainable Energy Reviews 30 (2014) 1019-1034. doi:10.1016/j.rser.2013.11.032. 
[54] H.-M. Henning, A. Palzer, A comprehensive model for the German electricity and heat sector in a future energy system with a dominant contribution from renewable energy technologies - Part I: Methodology, Renewable and Sustainable Energy Reviews 30 (2014) 1003-1018. doi:10.1016/j.rser.2013.09.012.

[55] J. Barton, S. Huang, D. Infield, M. Leach, D. Ogunkunle, J. Torriti, M. Thomson, The evolution of electricity demand and the role for demand side participation, in buildings and transport, Energy Policy 52 (2013) 85-102. doi:10.1016/j.enpol.2012.08.040.

[56] S. J. Cooper, G. P. Hammond, M. C. McManus, D. Pudjianto, Detailed simulation of electrical demand due to nationwide adoption of heat pumps, taking account of renewable generation and mitigation, IET Renewable Power Generation 10 (3) (2016) 380-387. doi: 10.1049/iet-rpg.2015.0127.

[57] P. E. Dodds, Integrating housing stock and energy system models as a strategy to improve heat decarbonisation assessments, Applied Energy 132 (2014) 358-369. doi:10.1016/j.apenergy.2014.06.079.

[58] F. Teng, M. Aunedi, G. Strbac, Benefits of flexibility from smart electrified transportation and heating in the future UK electricity system, Applied Energy 167 (2016) 420-431. doi:10.1016/j.apenergy.2015. 10.028 .

[59] S. Heinen, D. Burke, M. O'Malley, Electricity, gas, heat integration via residential hybrid heating technologies - An investment model assessment, Energy 109 (2016) 906-919. doi:10.1016/j.energy.2016.04. 126.

[60] A. Pensini, C. N. Rasmussen, W. Kempton, Economic analysis of using excess renewable electricity to displace heating fuels, Applied Energy 131 (2014) 530-543. doi:10.1016/j.apenergy.2014.04.111.

[61] X. Chen, X. Lu, M. B. McElroy, C. P. Nielsen, C. Kang, Synergies of Wind Power and Electrified Space Heatng: Case Study for Beijing, 
Environmental Science and Technology 48 (2014) 2016-2024. doi:10. 1021/es405653x.

[62] L. Hughes, Meeting residential space heating demand with windgenerated electricity, Renewable Energy 35 (8) (2010) 1765 - 1772. doi:10.1016/j.renene.2009.11.014.

[63] D. Connolly, H. Lund, B. V. Mathiesen, Smart Energy Europe: The technical and economic impact of one potential 100\% renewable energy scenario for the European Union, Renewable and Sustainable Energy Reviews 60 (2016) 1634-1653. doi:10.1016/j.rser.2016.02.025.

[64] J. Kiviluoma, P. Meibom, Influence of wind power, plug-in electric vehicles, and heat storages on power system investments, Energy 35 (3) (2010) 1244-1255. doi:10.1016/j.energy.2009.11.004.

[65] J. G. Kirkerud, E. Trømborg, T. F. Bolkesjø, A. G. Tveten, Modeling the Power Market Impacts of Different Scenarios for the Long Term Development of the Heat Sector, Energy Procedia 58 (2014) 145-151. doi:10.1016/j.egypro.2014.10.421.

[66] D. Liu, G. Zhang, B. Huang, W. Liu, Optimum Electric Boiler Capacity Configuration in a Regional Power Grid for a Wind Power Accommodation Scenario, Energies 9 (3). doi:10.3390/en9030144.

[67] M. Waite, V. Modi, Potential for increased wind-generated electricity utilization using heat pumps in urban areas, Applied Energy 135 (2014) 634-642. doi:10.1016/j.apenergy.2014.04.059.

[68] M. Kaltschmitt, W. Streicher, A. Wiese, Erneuerbare Energien - Systemtechnik, Wirtschaftlichkeit, Umweltaspekte, 5th Edition, Springer Vieweg, 2014.

[69] C. Verhelst, F. Logist, J. Van Impe, L. Helsen, Study of the optimal control problem formulation for modulating air-to-water heat pumps connected to a residential floor heating system, Energy and Buildings 45 (2012) 43-53. doi:10.1016/j.enbuild.2011.10.015. 
[70] J. Salpakari, J. Mikkola, P. D. Lund, Improved flexibility with largescale variable renewable power in cities through optimal demand side management and power-to-heat conversion, Energy Conversion and Management 126 (2016) 649-661. doi:10.1016/j.enconman.2016.08. 041 .

[71] J. Li, J. Fang, Q. Zeng, Z. Chen, Optimal operation of the integrated electrical and heating systems to accommodate the intermittent renewable sources, Applied Energy 167 (2016) 244-254. doi: $10.1016 / \mathrm{j}$. apenergy.2015.10.054

[72] P. Bayer, D. Saner, S. Bolay, L. Rybach, P. Blum, Greenhouse gas emission savings of ground source heat pump systems in europe: A review, Renewable and Sustainable Energy Reviews 16 (2) (2012) 1256 - 1267. doi:10.1016/j.rser.2011.09.027.

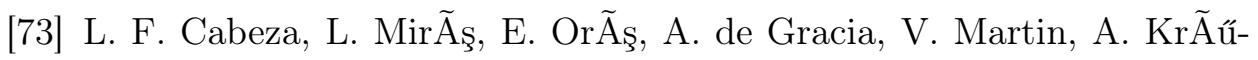
nauer, C. Rathgeber, M. M. Farid, H. O. Paksoy, M. MartÃynez, A. I. FernÂandez, Co2 mitigation accounting for thermal energy storage (tes) case studies, Applied Energy 155 (2015) 365 - 377. doi: $10.1016 / \mathrm{j}$.apenergy.2015.05.121

[74] H. Lund, B. Möller, B. V. Mathiesen, A. Dyrelund, The role of district heating in future renewable energy systems, Energy 35 (3) (2010) 13811390. doi:10.1016/j.energy.2009.11.023.

[75] A. Bolher, R. Casari, E. Fleury, D. Marchio, J. Miellet, Méthode de calcul des consommations d'énergie des bâtiments climatisés ConsoClim (1999). 


\section{Appendices}

\section{A. Further formulations to model heat pumps}

\section{A.1. Formulation by Georges et al. [38]}

Equations (8a) to (8c) are based on [75]. Equation (8d) determines the maximum power consumption for time slice $t$; equation $8 \mathrm{e}$ computes the actual power consumption in part-load mode. Note that part-load mode does not relate to the maximum installed capacity here, but to what is maximally possible under the temperature circumstances at a particular moment. Parameters $c_{i}, d_{i}$, and $f_{i}$ are based on manufacturer data and $n$ indicates under nominal conditions. Georges et al. 38] apply the same model for space heating and DHW heat pumps, with different supply temperatures.

$$
\begin{aligned}
\dot{Q}_{t}^{\text {max }} & =\left(d_{0}+d_{1}\left(T_{t}^{a}-T^{a, n}\right)+d_{2}\left(T_{t}^{\text {sink }}-T^{\text {sink,n }}\right)\right) \cdot \dot{Q}^{n} \\
\Delta T_{t} & =\frac{T_{t}^{a}}{T_{t}^{\text {sink }}}-\frac{T^{a, n}}{T^{\text {sink }, n}} \\
C O P_{t}^{\text {max }} & =\frac{C O P^{n}}{c_{0}+c_{1} \Delta T_{t}+c_{2} \Delta T_{t}^{2}} \\
P_{t}^{\text {max }} & =\frac{\dot{Q}_{t}^{\text {max }}}{C O P_{t}^{\text {max }}} \\
P_{t}^{\text {input }} & = \begin{cases}f_{1} \frac{\dot{Q}_{t}^{\text {output }}}{\dot{Q}_{t}^{\text {max }}} \cdot P_{t}^{\text {max }} \\
\left(f_{2}\left(\frac{\dot{Q}_{t}^{\text {output }}}{\dot{Q}_{t}^{\text {max }}}-0.3\right)+f_{3}\right) \cdot P_{t}^{\text {max }} & , \text { if } \frac{\dot{Q}_{t}^{\text {output }}}{\dot{Q}_{t}^{\text {max }}} \leq 0.3<\frac{\dot{Q}_{t}^{\text {output }}}{\dot{Q}_{t}^{\text {max }}} \leq 1\end{cases}
\end{aligned}
$$

\section{A.2. Formulation by Salpakari et al. [70]}

Using constraint (9a), Salpakari et al. [70] allow supply of heat pumps to the district heating network only below supply temperatures of $90^{\circ} \mathrm{C}$ (with $M$ as sufficiently big number). Likewise, heat accumulation in the piping network is only allowed for a temperature increase up to 15 Kelvin within 
each period $(9 \mathrm{~b})$.

$$
\begin{gathered}
P_{t}^{\text {input }} \leq P^{\max }= \begin{cases}M & \text { if } T_{t}^{\text {sink }} \leq 90\left[{ }^{\circ} C\right] \\
0 & \text { if } T_{t}^{\text {sink }}>90\left[{ }^{\circ} C\right]\end{cases} \\
P_{t}^{\text {input }} \cdot C O P^{\text {average }} \leq c \cdot \dot{m} \cdot \max \left(\min \left(T_{t}^{\text {sink }}+15[K], 90\left[{ }^{\circ} C\right]\right)-T_{t}^{\text {sink }}, 0\right)
\end{gathered}
$$

where $c$ and $\dot{m}$ represent the specific heat capacity of water and its mass flow respectively.

\section{A.3. Formulation by Waite and Modi [67]}

Waite and Modi [67] use data from heat pump manufactures for $P^{H P}$ and $\dot{Q}^{H P}$ at different ambient temperatures to compute a temperature dependent COP (10a). They augment their formulation to include an auxiliary electric boiler, whose use is triggered when the ambient temperature falls below a pre-determined design temperature $T^{\text {design }}$ according to equation $10 \mathrm{~b}$. $H D(T)$ renders the heating degree at temperature $T$ and $\eta^{E B}$ the electric boiler's efficiency.

$$
\begin{gathered}
C O P\left(T^{\text {source }}\right)=\frac{\dot{Q}^{H P}\left(T^{\text {source }}\right)+\dot{Q}^{E B}\left(T^{\text {source }}\right)}{P^{H P}\left(T^{\text {source }}\right)+P^{E B}\left(T^{\text {source }}\right)} \\
\dot{Q}^{E B}(T)= \begin{cases}0 \quad & \text { if } T^{\text {source }} \geq T^{\text {design }} \\
\frac{H D\left(T^{\text {source }}\right)}{H D\left(T^{\text {design }}\right)} \cdot \dot{Q}^{H P}\left(T^{\text {design }}\right)-\dot{Q}^{H P}\left(T^{\text {source }}\right) & \text { if } T^{\text {source }}<T^{\text {design }}\end{cases} \\
P^{E B}\left(T^{\text {source }}\right)=\eta^{E B} \cdot \dot{Q}^{E B}\left(T^{\text {source }}\right)
\end{gathered}
$$

